\title{
How Do Investors Perceive the Materiality of Data Security Incidents
}

\author{
Ahmad H. Juma'h, University of Illinois, Springfield, USA* \\ (iD) https://orcid.org/0000-0002-1077-0944 \\ Yazan Alnsour, University of Wisconsin Oshkosh, USA \\ iD https://orcid.org/0000-0001-7198-7197
}

\begin{abstract}
Data security incidents are continually increasing; hackers, governments, and other actors increasingly attempt to gain unauthorized access to confidential data. Information systems (IS) users are becoming more vulnerable to the risks of data breaches. Many stakeholders perceive cybersecurity incidents as indicators of firms' operational and technological internal deficiencies. Previous research has revealed that investors react negatively to data breaches, yet little is known about investors' reactions to material data security incidents. Using a sample of 232 data security incidents for 132 publicly traded companies in the United States, the authors applied an event study methodology to discern investors' reactions to material versus immaterial incidents. They also use multivariate regression and time-to-event analysis to examine what determines the degree of investors' reactions, considering several intervals around the event day. The results show that investors perceive material data security incidents as a deficiency of breached companies in comparison to immaterial incidents.
\end{abstract}

\section{KEYWORDS}

Data Breaches, Information Security, Investors Reactions, Materiality, Survival Analysis

\section{INTRODUCTION}

The ongoing growth in the collection, storage, and analysis of data brings new opportunities and challenges for both practitioners and researchers in the fields of information systems, finance, and accounting. The sensitivity of stored data and information privacy are concerns for all firms' stakeholders (Park et al., 2018; Park \& Shin, 2020). The benefits obtained from collecting data about customers, potential customers, employees, creditors, and investors, among others, are not without risks. For example, in the California Data-Breach Report, nearly three out of five Californians were victims of a data breach in 2015 alone (Harris, 2016). The recent public health crisis has made companies rely even more on information systems for the continuity of their operations. Thus, organizations are becoming more vulnerable to perpetrators of sensitive data that could weaken the organization's performance and reputation.

A data breach refers to internal or external unauthorized access to or use of a firm's data in a way that compromises the confidentiality, integrity, or availability of the data. Companies guarantee the availability of data for authorized users when needed to meet the firms' objectives. Also, 
firms safeguard the integrity of data by employing and implementing preventive measures against unauthorized or accidental modifications, loss, or disclosures (Rosati et al., 2019; Yayla \& Hu, 2011; Goel \& Shawky, 2009). There are many types of information and cybersecurity incursions, such as data manipulation, alterations, or theft, and malicious malware intrusions, such as viruses, logic bombs, worms, Trojan horses, backdoors, spyware, and ransomware, which may financially damage a firm's reputation (Rosati et al., 2018; Sen \& Borle, 2015; Shabtai et al., 2012). Firms adopt security procedures and policies that are related to the inherent risk of their information systems by using data encryption, firewalls, data backups, and off-site rotations, and engaging in continuing planning (Yayla \& Hu, 2011; Schmidt et al., 2008).

Compliance with IS security policies is an important factor that the end-users and employees should abide by to prevent breaches. Not protecting firms' assets increases the possibility of cybersecurity incidents due to human behavior that can be responsible for losses of (portable) assets (Chen et al., 2015). Considerable cybersecurity incidents also occur from inside_cyberattacks that are related to unethical or behavioral issues of employees ( $\mathrm{Li}$ et al., 2019). Employees may use neutralization techniques to rationalize IS policy violations; these violations plague firms worldwide (Teh et al., 2015) and affect firms' reputations. The IS culture improves employees' security awareness, and through training, firms can improve employee's security behavior (Lyu \& Zhang, 2015). Dinev et al. (2006) argue that individuals react differently based on their culture, and therefore through employee training, firms can enhance employee relations and encourage accountability and engagement in complying with IS policies (He \& Zhang, 2019; Yaokumah et al., 2019).

Research in information security economics provides insights regarding the restrictions, prevention, cost, and concerns of data breaches (Shin, 2010). Firms employ different practices to limit unauthorized use of private data. Examples of these practices include, first, investing in assets (tangible and intangible) to avoid cybersecurity incidents (Gordon \& Loeb, 2002; Gordon et al., 2010; Schlosser et al., 2006); second, ensuring internal control effectiveness, especially information systems (IS) controls and strengthening the internal and external examinations of data-related activities, including information security auditing, IS auditing, internal auditing, and external auditing (Cavusoglu et al., 2004, 2005; Rosati et al., 2017; Sen \& Borle, 2015); third, management and monitoring of relationships with related parties, including customers and other data users (Acquisti et al., 2018; Acquisti et al., 2006; Ayyagari, 2012; Kokolakis, 2017); and fourth, compliance with local and international regulations and laws (Fotiadis and Yu, 2019; Shin et al., 2019; Acquisti et al., 2018; Acquisti et al., 2013; Romanosky et al., 2011; Png et al., 2008).

Previous research investigated the effect of data breaches on firms' performance, but there is a gap in addressing the effects of qualitative materiality of cyberattacks. This study bridges the current research gap by empirically investigating the effect of the breach's materiality (quantitative and qualitative) on shareholders' perception of firms' performance. We measure the severity of the cybersecurity incidents by its materiality, quantitively measured by the number of breached records. We expect that investors react to data breach incidents with a larger volume of records, as quantitatively material events. We measure the qualitative materiality of breach incidents by the affected company's disclosure of internal control deficiencies, and when and how the announcement was made. Data breaches may occur because of the weakness of internal operations and controls (Lawrence et al., 2018). Management decides about the pervasive materiality of any events that have effects on reporting on the weakness of internal controls (Tan \& Yu, 2018). Reporting weakness of the internal control system shows that breached firms consider issues that might influence stakeholders' interests. By disclosing information about data breaches in the notes of the financial statements, affected firms respond to cybersecurity incidents to mitigate the firm's risks and obligations. Thus, we address the relationship between the materiality of data breach incidents and firms' self-disclosure of any aspects of these incidents. Also, by using time-to-event analysis, we studied three perspectives relating to prolonging the breaches' effects on cumulative excess returns of breached firms. These perspectives are the timing of disclosing information about breaches (before and after 2018 because 
of SEC guidance regarding reporting cybersecurity attacks), whether any information is included in the financial statements about the breach incidents, and type of breach (hacked or not).

Accordingly, we aim to answer the following research questions (RQs):

1) How does the materiality of data breach incidents affect investors' perception of the company's performance?

2) How do investors react to data breach announcements of companies that self-disclose of weakness in internal controls?

3) How do certain data breach characteristics prolong the negative perception by investors about cybersecurity attacks?

The remainder of this paper proceeds as follows: Next section, we review related literature, which provides the foundation for theoretical background for our hypotheses. Following that, we describe the research methodology and statistical analyses. The paper concludes with a discussion of the study's results, practical and managerial implications, limitations, and suggests areas for future research.

\section{THEORETICAL BACKGROUND AND HYPOTHESIS DEVELOPMENT}

A variety of empirical studies have been used to evaluate data breaches' effects on organizations' performance, including field studies (Acquisti et al., 2006; Martin et al., 2017) and surveys (Richardson \& Director, 2008). Examples of indicators that have been used to study short-term effects of data breach announcements include firms' profitability, liquidity, solvency, leverage, and changes in share prices before and after the announcements (Sen \& Borle, 2015; Nofer, 2015; Nofer et al., 2014; Yayla \& Hu, 2011; Goel \& Shawky, 2009; Cavusoglu et al., 2005).

We reviewed studies on data breaches' effects on firms' performance, pursuing to recognize significant factors influencing investors' negative perception. We used data breaches, cyberattacks, cybersecurity, and data security incidents as the keywords to search the Web of Science Core Collection databases, the AAA Digital Library, the Wiley Online Library, Taylor \& Francis Online, and Elsevier. We filtered the resulting articles to ensure they examined data breaches' effects on excess returns (ERs) by using event studies. The selected articles differ regarding the negative perception of investors' reaction to data breach events based on breach type, repetition, number of records, firm classification, and how quickly it takes a company to return to positive ERs.

For example, Schatz \& Bashroush (2016) found weak statistical evidence that the market reacts differently to subsequent breach events affecting the same firm. Rosati et al. (2017) studied data breach announcements as a potential source of asymmetric information, and they found that these announcements have a positive short-term effect on both bid-ask spread and trading volume on event day, no effects on the day before the event, and then quickly return to normality after the event day. Twenboah-Kodua et al. (2018) found that cumulative effects of cyberattacks on prices of financial sector firms tend to react cumulatively to cyberattacks over three days than other sectors, and technology firms tend to be less reactive to the breach announcements because they might have the necessary techniques to address large-scale cyberattacks. Using a sample of 87 data breaches from 73 US publicly traded firms from 2011 to 2014, Rosati et al. (2019) found that the use of social media exposure at the time of a data breach exacerbates the negative stock price to the announcement.

Based on our literature review, we have selected twenty-nine studies that investigated the effect of data breaches on firms' ER. Twenty-two found negative effects on companies' ERs, while the rest of the studies found no evidence of negative effects (See Appendix D). Most of these studies used a conventional event study, and a few empirical studies used event studies with multiple regressions (Malhotra \& Kubowicz Malhotra, 2011; Wang, 2010). A few gaps can be recognized in the literature. First, most of the articles investigated the cyberattack influences on ERs using smaller event intervals around the event day (e.g., Deane et al., 2019; Chatterjee et al., 2019), and some articles used relatively 
larger event intervals but found no significant negative effects (e.g., Richardson et al., 2019; Kannan et al., 2007; Hovav \& D'Arcy, 2003). Second, limited studies differentiated between data breach types, repeated breaches, and industry classification (e.g., Tweneboah-Kodua et al., 2018). Third, based on our search, no studies have associated SEC (2018) guidance and companies' reporting to mitigating cyberattacks risks and obligations. Therefore, we expand the existing research by investigating what factors prolong investors' reactions to data breach announcements. In the next section, we discuss the research hypotheses.

\section{Capital Market Efficiency}

According to the classical finance theory, investors continually measure investment risk and return based on the availability of information. The risk is related to both internal and external factors. Investors rapidly react to new information, such as announcements of new products, strategic alliances, acquisitions, earnings, stock splits, dividends, and accounting changes. Investors consider data breach announcements as an indication of internal inefficiencies and external threats that may increase companies' risk factors (Wang \& Ngai, 2018). One question about the efficient market hypothesis is whether it is sufficiently valid to provide a practical framework for studying the behavior of share prices concerning announcements of data breaches. Fama (1970) suggested three levels of market efficiency: strong, semistrong, and weak. Strong-form efficiency refers to an information subset that contains all information, whether publicly available or not, and the stock share prices reflect all the information. For semistrong efficiency, it should not be possible to make returns higher than the market average by investing after the release of new information. For weak-form efficiency, all information is contained in past share price data and is fully reflected in current prices.

An assumption that the stock market is informationally efficient, at least in the semistrong form, implies that the market reflects all available information in current, preannouncement prices before the release of new information about an event (Fama, 1970; Fama \& French, 2017; Tucker, 1994). We assume that ERs encountered in the post-event window are attributable to the new information. Investors react to an announcement of firm events when they perceive that these events probably affect a firm's image, performance, or obligations. Therefore, the magnitude and type of data breach influence investor perception of the event materiality.

All public information is available to market participants through the price-signaling mechanism, and the stock market processes information rapidly. The simultaneous and complete disclosure of available information leads to consistent expectations, with all information incorporated in the spot price (Fama \& French, 2018; Fama \& Miller, 1972). Investors perceive the materiality of an event differently than accountants and auditors. DeZoort et al. (2019) state that investors focus on different indicators when formulating materiality judgment, thus, the stock market should not react significantly to immaterial data breaches and cybersecurity incidents. This would occur when the incident's announcement is considered noninformative and is part of already anticipated risks or economic effects. Based on the previous discussion, we hypothesize:

H1: The material data breach incidents have a negative effect on the excess returns of breached firms.

\section{Internal Control Deficiencies}

To mitigate the risks of data breaches and security incidents, companies ensure adequate controls of their information systems by developing different auditing techniques for the physical and virtual systems. The inefficiency of internal controls increases the opportunity for perpetrators to access sensitive data. Additionally, firms must continually improve their controls through preventive measures because hackers are becoming more sophisticated in IS attacks. Bandyopadhyay et al. (2014) stated that IT security planning should not remain an internal decision. Also, Xu et al. (2017) found that investors react favorably to companies that align their investments in IT security with their strategy. 
Investors evaluate indicators of firms' weaknesses regarding strategic decisions and routine and operational activities. Data breaches can be perceived as a signal of the weakness of internal operations and controls (Lawrence et al., 2018). Therefore, these events may increase the obligations of breached firms that may include legal and ethical liabilities that affect their financial strength. Many organizations have been faced with consumer class action lawsuits and shareholder litigations and claims allegedly arising out of data breach incidents, seeking monetary damages or other relief (Hooker \& Pill, 2016). Management cannot deny full responsibility for cybersecurity incidents because of its responsibility for maintaining an effective internal control system.

Accounting standard setters indicate that control systems can provide reasonable assurance for internal control effectiveness (Committee of Sponsoring Organizations of the Treadway Commission COSO, 2013). Although management has not much discretion for reporting internal control weakness (SEC, 2003), they can decide about the materiality of such weakness that has effects on reporting on internal control weakness (Tan \& Yu, 2018). Reasonable assurance's vague definition gives managers discretion on what to divulge in their internal control reports (Piercey, 2009). When prevention controls do not protect data from perpetrators, firms become liable to stakeholders and incur short-run expenses, such as investments in technology, consultancy fees, investigation costs, and legal fines. Based on that, we propose the following hypothesis:

H2: Self-disclosure of weakness in internal controls has a negative effect on the excess returns of breached firms.

\section{Cybersecurity Regulations and Accounting Standards}

The security of data is covered by many U.S. laws and regulations, such as the U.S. Foreign Corrupt Practices Act, SEC regulations, the Health Insurance Portability and Accountability Act of 1996, the Health Information Technology for Economic and Clinical Health Act, and the Gramm-Leach-Bliley Act, as well as numerous state laws governing personal information.

In October 2011, the SEC Division of Corporation Finance issued guidance (SEC, 2011) regarding disclosure obligations about cybersecurity risks and incidents for the significant costs, remediation, litigation, regulatory fines, and other losses associated with breaches; the guidance also required that investors be informed of important or material news. In February 2018, the SEC released a Commission Statement and Guidance on Public Company Cybersecurity Disclosures (SEC, 2018) to assist public companies in preparing disclosures about cybersecurity risks and incidents. The release of this document is an indication that cybersecurity incidents should be timely reported on company financial statements.

Companies conducting business or trading in stock markets in the U.S.A. should follow the U.S. generally accepted accounting principles. The quality of financial reports is affected by the accountants' considerations and judgments. To estimate the effect of an economic event on a company's financial health, accountants use their experience and judgment to interpret the existing rules in preparing financial reports (Bernardi \& Pincus, 1996; Boatsman \& Robertson, 1974). Material considerations and accounting treatment of contingent liabilities concerning data breach obligations are crucial elements for inclusion in the notes accompanying financial statements.

Because an accountant's interests may be different from those of a firm's objectives, the accountant's consideration of materiality can be subverted when he or she maximizes benefits for the accounting firm instead of those for the firm. The difficulty of establishing a measurable code of conduct in accounting, auditing, and management, among other disciplines, increases the dependence on accountants' perceptions in considering the materiality of an economic event (Hitzig, 2016; Juma'h, 2014).

Users of financial statements often observe that the statements and accompanying notes constitute a generic form of presenting information and do not provide adequate information for stakeholders 
(EY, 2014). New rules and guidance are usually adopted by accounting and governmental authorities after a major scandal or problem in accounting practices (van Driel, 2019). The SEC (2018) release is a result of the increase in cybersecurity attacks and the need to offer guidance to public companies for disclosure purposes. The SEC regulations increase the institutional pressures on breached companies (Feroz et al., 1991) to consider the inclusion of data breaches somehow in the notes of the financial statements. Thus, we expect the following hypothesis:

H3: Self-disclosure of information concerning data breach incidents is associated with the number of records breached.

The characteristics of data breaches measured by the type of data breaches as hacked or other types, the magnitude of data breaches measured by the number of records, and when a breach occurred (i.e., before or after the SEC (2018) guidance about cybersecurity) can give a signal to an investor about the materiality of data breach incidents and affect their longer negative perception of these incidents. Therefore, we hypothesis:

H4: Data breach characteristics (e.g., type and magnitude) prolong the negative perception of investors regarding breached companies' performance.

\section{RESEARCH METHODOLOGY}

We used the event study methodology to determine the ERs and cumulative ERs (CERs) of breached companies. See Appendix B for more details. To analyze the data breach incidents' (quantitative and qualitative) materiality effect on CER, we used multivariate regression analysis. In addition, to investigate how different factors may prolong the effect of data breach incidents on CER, we applied time-to-event analysis techniques. In the paragraphs below, we discuss the methodologies we used.

After identifying affected companies of cybersecurity incidents, we classify them by the announcement's dates, type of breaches, and volume of records. The data breach event day is labeled as time $t_{0}$. For each security, 255 daily return observations before $t_{0}$ and 20 observations after $t_{0}$ were collected. The first 250 days in this period were used as the estimation window to calculate statistical parameters. We followed Brown and Warner (1985) in the selection of these days in the estimation window; the 250 labor-days are equivalent to one year that captures a good estimation of statistic parameters to use in the analysis. The five days before and 20 days after the event day $\left(\mathrm{t}_{0}\right)$ was used to create windows of various lengths to investigate pre- and post-event returns. The 20 days after $\mathrm{t}_{0}$ are used in the multivariate analysis and in the time-to-event (survival) analysis to show how quick the recovery is from the negative effect of the event. Our event window is relatively larger than previous studies to measure the longer effect of data breaches on the company's performance.

The inclusion of preannouncement days in the window is a response to the difficulty of identifying with certainty when the stock market receives new information about data breaches. An individual test of each company's ERs before the event was therefore made. However, it was reassuring that almost all companies had reactions on the announcement day or the next day, so these two days were considered jointly to capture some release of new information, although we could not judge whether the information was entirely new at the announcement date. Given the length of sample observations and the number of events in the sample, effects such as account length, weekends, and nonworking days (Fama et al., 1969) were regarded as immaterial and ignored in calculating returns.

We used multivariate regression to explain the CER considering the number of records affected, systematic risk ( $\beta$ ), types of breaches, size of the company, industry-fixed effect, and year-fixed effect to minimize the effect of omitted variable bias. The panel data sets enable flexibility in modeling differences across firms in the sample. We used the OLS model as follows: 
$y_{i t}=X_{i t}^{\prime} \beta+Z_{i t}^{\prime} \alpha+e_{i t}$. Each company effect is $Z_{i t}^{\prime} \alpha$, where $Z_{i}$ contains a constant term and a set of specific variables related to each company or business classification. For the identification of specific variables, we used financial ratios as explaining variables. When $Z_{i}$ contains only a constant term, pooled regression is recommended. We considered the fixed effects in constructing the regression model. In considering fixed effects, if $Z_{i}$ is unobserved but correlated with $X_{i t}$, the OLS of $\beta$ is biased and inconsistent because of omitted variables, and the model is $y_{i t}=X_{i t}^{\prime} \beta+\alpha_{i t}+e_{i t}$ (Greene, 2012). In this paper, we used the following multiple regression: $y_{i t}=X_{i t}^{\prime} \beta+$ year $^{*}$ dummies $+N A I C S^{*}$ dummies $+e_{i t}$, where $y_{i t}=\mathrm{CER}_{\mathrm{it}}$ and Xi's are the explaining variables.

Also, we used multiple regression with dummy variables to explain the accountant's consideration of a data breach as a contingent liability and the inclusion in the company's 10-K statement or possible operating or technology deficiencies, and whether the affected companies have reported any internal control deficiencies in the management's report. We used a t-test to verify the level of significance to include a variable in the regression model, F-test to verify the overall fitness, and adjusted $\mathrm{R}^{2}$ to determine how the included variables explain the CERs in the models. We used binary variables for explained (dependent) variables (Studenmund, 2011). In the case of determining the effect of the difference between companies disclosing data breach information in the 10K (10KDB), we assigned one (1) for $10 \mathrm{KDB}$, if a company includes information about the data breach in the $10 \mathrm{~K}$, and zero (0) otherwise. Also, we explored the factors that explain the negative CER (NCER) that lasts for a longer period $[0,20]$.

When we deal with binary outcomes like yes/no or on/off, for instance, such outcomes are easily analyzed with traditional methods like the binary logistic regression. The binary regression, though, does not consider time in the analysis and how that affects the outcome (Efron, 1988). For example, if we are studying cancer and we would like to know the time that it takes until the recurrence of cancer using traditional methods, that would not be sufficient since they do not take the time aspects as an outcome in the model. Also, conventional statistical methods cannot handle censoring, which is a special case with the subject of interest that may not experience a given event during the observation window (Rao, 2003).

The time-to-event analysis is used to estimate the time for an entity in a specific population to experience an event of interest. Survival analysis is a type of time-to-event analysis that was initially developed in healthcare and is widely used in that area of research (George, Seals, \& Aban, 2014). The technique over the years has been applied in other areas, like predicting the lifetime of machines or other artifacts. The birth event can be considered as the production of a machine, and the death event the malfunction of that machine (Ting, 2012). Survival can be anything, and it does not have to be dead or alive. It could be the time until an event like predicting churning employees or customers (Van den Poel \& Lariviere, 2004) or the time for a particular task to be completed (Wang et al., 2011). It can also be a desired event; for example, Chatterjee et al. (2019) used survival analysis to find the time needed for a stock to reach the desired price to sell for a targeted return after a technical or a fundamental call. Also, Huang et al. (2019) used the Kaplan-Meier (K-M) estimator to quantify the level of persistence in lagged correlations between the Google Trends volume and the directional movements in the S\&P 500. In our research, we set the starting point to be the data breach event until the company's CERs become positive.

Survival curves (also known as K-M curves) plot the percent of entities that did not experience the event of interest as a function of time. Typically, we want to compare the curves of two different groups. The log-rank test (also seen in the literature by the name of Mantel-Haenszel) is used to compare the different curves. In the K-M plots, the time is plotted on the $\mathrm{x}$-axis, while the probability that the event has not yet happened is plotted on the y-axis. Each downward step in the curves presents an outcome of interest (Harrell, 2015; Ribeiro, 2017). 
Table 1. Descriptive Statistics for Breached Companies, $n=232$

\begin{tabular}{|l|l|l|l|l|}
\hline \multicolumn{1}{|c|}{ Variables } & \multicolumn{1}{|c|}{ Average } & \multicolumn{1}{c|}{ Maximum } & \multicolumn{1}{c|}{ Minimum } & $\begin{array}{c}\text { Standard } \\
\text { deviation }\end{array}$ \\
\hline Total revenue & $241,957,769$ & $29,379,510,000$ & 616,000 & $2,408,381,404$ \\
\hline Operating income & $4,287,673$ & $51,301,000$ & $-30,363,000$ & 8,693 \\
\hline Total assets & $143,280,309$ & $2,187,631,000$ & $3,670,255$ & $390,244,000$ \\
\hline $\begin{array}{l}\text { Number of } \\
\text { employees }\end{array}$ & 108,351 & $2,300,000$ & 93 & 285,186 \\
\hline Capitalization & 170,438 & $4,223,618$ & 88 & 659,436 \\
\hline
\end{tabular}

\section{Data Collection}

The first step in constructing the sample was to identify the publicly reported data breaches from the Privacy Rights Clearinghouse, which contains 8,806 events since 2005. We identified 802 events for publicly traded companies in the United States. We focused on publicly traded companies, because the SEC mandates these companies to report their financial performance and major event on a timely basis, and this is not required for non-publicly traded companies that have no share prices which is fundamental to the event study analysis. From these events, we identified 301 events for 152 companies that disclosed the number of records breached. Only 232 events were found for 132 companies with the required financial variables used in the analysis. These 232 events constituted our final sample.

\section{Data Description}

The distribution, by year, of data breach announcements in the sample is given in Appendix A, Table A1. Of these events, $13 \%$ occurred in the year 2014. The two-digit NAICS classification of the companies in the sample is given in Appendix A, Table A2. The finance, insurance, and manufacturing sectors had the most data breach events. Table 1 shows the descriptive statistics for the final data breach sample. The six variables in the table: total revenue, operating income, total assets, number of employees, and capitalization of sample companies demonstrate the companies' size.

Table 2 shows the distribution of the number of records breached. About $51 \%$ of the events were

Table 2. Number of Records Breached, by Volume and Distribution

\begin{tabular}{|l|l|l|}
\hline \multicolumn{1}{|c|}{ Frequency } & \multicolumn{1}{|c|}{ Number of events } & Percentage of events \\
\hline $1-9,999$ & 119 & $51.29 \%$ \\
\hline $10,000-99,999$ & 62 & $26.72 \%$ \\
\hline $100,000999,999$ & 28 & $12.07 \%$ \\
\hline $1,000,00-99,999,999$ & 19 & $8.19 \%$ \\
\hline$>100,00,000$ & 4 & $1.72 \%$ \\
\hline Total & 232 & $100 \%$ \\
\hline
\end{tabular}

related to fewer than 10,000 records; this is an important determinant to consider in the analysis of the total effect of a breach.

Zafar, Ko, and Osei-Bryson (2016) stated that the data breach affects performance depending on the type of security breach. The types of data breaches in the sample are shown in Appendix A, Table 
A3. The hack type represented close to $19 \%$ of all events. Table 3 shows that about $35 \%$ of companies had two or more incidents of breaches. This statistic is an indication of the seriousness of the problem.

\section{RESULTS AND DISCUSSIONS}

\section{Table 3. Number of Data Breach Events}

\begin{tabular}{|l|l|l|}
\hline \multicolumn{1}{|c|}{ Number of events } & \multicolumn{1}{c|}{ Number of firms } & \multicolumn{1}{c|}{ Percentage of firms } \\
\hline 1 & 86 & $65.15 \%$ \\
\hline 2 & 29 & $2197 \%$ \\
\hline 3 or more & 17 & $12.88 \%$ \\
\hline Total & 132 & $100.00 \%$ \\
\hline
\end{tabular}

Investors perceived a negative effect of data breaches in about $55 \%$ of the events. This implies that investors consider the material data breach announcements and did not classify all of them as negative news. Because we considered announcements regarding data breaches that did not indicate the number of affected records as nonmaterial events, we used only the announcements that included this number in the verification of stock market reaction.

Event study results (see Table 4) validated that investors perceived data breach events negatively. On average, the ER was negative but not significant $(\alpha=0.05)$ at $t_{-1}$, but it was negative and significant $(\alpha=0.05)$ at $\mathrm{t}_{0}$ and $\mathrm{t}_{1}$. The CER was negative and significant $(\alpha=0.05)$ until two weeks $(12$ trading days) after $\mathrm{t}_{0}$. This is consistent in showing that data breach events were perceived negatively over a short period. However, the investors' negative perception diminished over an intermediate period. A possible explanation for investors' diminishing negative perception is that the available information regarding companies' announcements to mitigate the risks resulting from the breaches reduces the investors' perceived negative effect in a short-term period.

The event study results were consistent with the correlation between CER and the number of records breached, and the results are significant at 5\% level. (See Appendix C, Table C1.) Also, we used multiple regression with dummy variables to explain the determinants that affected CER at several intervals after the event day. As indicated by event study results, the number of records had an inverse sign with CER and was significant $(\alpha=0.05)$ on several intervals, as shown in Appendix $\mathrm{C}$, Table $\mathrm{C} 2$. These results confirm hypothesis one regarding the quantitative dimension measured by the number of records that has a significant effect on investors' reaction to breach events. As shown in Table C3 of Appendix C, MRICD is significant ( $\alpha=0.05)$; this is confirming our hypothesis 2 related to the reporting of internal control deficiencies by management related to the negative perception of investors.

Regarding using fixed effects by year and industry, the data showed no significance $(\alpha=0.05)$ regarding the year specificity or industry type; this indicates that the models that we used explain the CER and minimize the effects of the omitted other variables. The main factor encountered in this research is the volume of the breach, and it is not related to a specific industry or a specific year, despite that in some years-like the year 2014 — there are more data breaches in comparison to other years in our sample.

\section{Cybersecurity Consideration in Financial Statements}

We analyzed the 132 companies that suffered data breaches, and we found that 26 of them included information about the breaches in their financial statements. The reported information signals the 
Table 4. Event Study Results for Data Breach Events That Included the Number of Records in the Announcement Using OLS Market Model

\begin{tabular}{|c|c|c|c|c|c|c|c|c|}
\hline $\mathbf{T}$ & Aer & T-test & $\begin{array}{c}\begin{array}{r}\text { Event } \\
\text { window }\end{array}\end{array}$ & aer Cum & T-test & $\begin{array}{r}\text { Event } \\
\text { window }\end{array}$ & aer $\quad$ Cum & T-test \\
\hline-1 & $-0.0597 \%$ & -0.39 & & & & & & \\
\hline 0 & $-0.2441 \%$ & $-1.60^{*}$ & {$[-1,0]$} & $-0.304 \%$ & $-1.41 *$ & & & \\
\hline 1 & -0.2672 & $-1.75^{*}$ & {$[-1,1]$} & $-0.571 \%$ & $-2.16^{* * *}$ & {$[0,1]$} & $-0.511 \%$ & $-2.37 * *$ \\
\hline 2 & $0.0274 \%$ & 0.18 & {$[-1,2]$} & $-0.544 \%$ & $-1.78^{*}$ & {$[0,2]$} & $-0.484 \%$ & $-1.83^{*}$ \\
\hline 3 & -0.0495 & -0.33 & {$[-1,3]$} & $-0.593 \%$ & $-1.74 *$ & {$[0,3]$} & $-0.534 \%$ & $-1.75^{*}$ \\
\hline 4 & -0.2849 & $-1.87^{*}$ & {$[-1,4]$} & $-0.878 \%$ & $-2.35 * *$ & {$[0,4]$} & $-0.818 \%$ & $-2.40^{* * *}$ \\
\hline 5 & $-0.1440 \%$ & -0.95 & {$[-1,5]$} & $-1.022 \%$ & $-2.54 * *$ & {$[0,5]$} & $-0.962 \%$ & $-2.58 * *$ \\
\hline 6 & $0.0683 \%$ & 0.45 & {$[-1,6]$} & $-0.954 \%$ & $-2.21 * *$ & {$[0,6]$} & $-0.894 \%$ & $-2.22 * *$ \\
\hline 7 & $0.0951 \%$ & 0.62 & {$[-1,7]$} & $-0.859 \%$ & $-1.88^{*}$ & {$[0,7]$} & $-0.799 \%$ & $-1.85^{*}$ \\
\hline 8 & -0.0427 & -0.28 & {$[-1,8]$} & $-0.901 \%$ & $-1.87 *$ & {$[0,8]$} & $-0.842 \%$ & $-1.84 *$ \\
\hline 9 & -0.0980 & -0.64 & {$[-1,9]$} & $-0.999 \%$ & $-1.98^{*}$ & {$[0,9]$} & $-0.940 \%$ & $-1.95^{*}$ \\
\hline 10 & -0.0238 & -0.16 & {$[-1,10]$} & $-1.023 \%$ & $-1.94 *$ & {$[0,10]$} & $-0.963 \%$ & $-1.91 *$ \\
\hline 11 & -0.1689 & -1.11 & {$[-1,11]$} & $-1.192 \%$ & $-2.17^{*}$ & {$[0,11]$} & $-1.132 \%$ & $-2.15^{*}$ \\
\hline 12 & $0.1073 \%$ & 0.70 & {$[-1,12]$} & $-1.085 \%$ & $-1.90 *$ & {$[0,12]$} & $-1.025 \%$ & $-1.87^{*}$ \\
\hline 13 & $0.3364 \%$ & 2.21 & {$[-1,13]$} & $-0.748 \%$ & -1.27 & {$[0,13]$} & $-0.689 \%$ & -1.21 \\
\hline 14 & $0.0119 \%$ & 0.08 & {$[-1,14]$} & $-0.736 \%$ & -1.21 & {$[0,14]$} & $-0.677 \%$ & -1.15 \\
\hline 15 & -0.0276 & -0.18 & {$[-1,15]$} & $-0.764 \%$ & -1.22 & {$[0,15]$} & $-0.704 \%$ & -1.16 \\
\hline
\end{tabular}

materiality of the event from a qualitative perspective. The disclosures were related to contingent liabilities from litigation and risk factors. The contingent liabilities were reported according to the probability of occurrence and the reasonable estimation of the obligations. For example, Equifax, in its 2012 and 2016 10-K statements, recognized the possibility of the occurrence of a data breach and the fact that the company is regularly the target of attempted cyber- and other security threats; the notes in the $10-\mathrm{K}$ statements were identical. However, in the notes to its $201710-\mathrm{K}$ statement, Equifax described the major breach that occurred in 2017, recognized the probability of contingent liability, and indicated that it was reasonably estimated. The TJX data breach incident in 2007 was considered a contingent liability as a result of punitive class-action lawsuits that were filed in state and federal courts.

The data breach incidents suffered by Facebook in 2018, Anthem in 2015, and Community Health Systems in 2014 can be considered as probable contingent liabilities, but reasonable estimations were not provided. For the breaches suffered by Verizon Communications in 2017 and Apple in 2012, notes indicated the possibility of occurrence, again without reasonable estimations. Of companies that described the data breach possibility in their 10-K statements, $85 \%(22 / 26)$ described events that occurred after 2011 and after the SEC made public the cybersecurity guidance. The companies that included a note about contingent liability as a result of data breach incidents had class-action suits.

Table $\mathrm{C} 4$ in Appendix $\mathrm{C}$ shows that CER is related to management inclusion of information about the occurrence of data breaches or possible operational or technological deficiencies in the notes accompanying financial statements. The regression results show that the inclusion of data breach incidents in the $10-\mathrm{K}$ statements is significantly $(\alpha=0.01)$ associated with the number of records. Data breach information (10KDB) is related to the inclusion of the contingent liabilities, possible liabilities, or as a possible threat in connection with the data breach incidents in $10-\mathrm{K}$ statements. These results confirm the third hypothesis that companies report data breaches when the number of records affected is large. Also, in Table C5 in Appendix C, the regression showed that a negative 
longer effect $\left[\mathrm{t}_{0}-\mathrm{t}_{20}\right]$ was associated with a larger number of affected records and was marginally significant $(\alpha=0.10)$. These results confirm that the negative perception of investors decreases in a short period as a consequence of companies' management of the data breach risks.

\section{Time-To-Event Analysis}

Figure 1 shows the two K-M curves of the breaches before and after 2018; by comparing the two curves, we can see a significant separation between the curves. The difference between the curves was tested using the log-rank test. The test resulted in an insignificant chi-square, which yields to the rejection of the null hypothesis that indicates that the two curves are equal. We can also see from Figure 1 that by the end of the observation window, 33.5\% of the companies breached after 2018 yet to reach a positive cumulative return in comparison to $25 \%$ of the companies breached before 2018 . However, most of the companies reached a positive cumulative return from the breach event within a window of 5 days.

Figure 2 shows the two K-M curves of the breaches by external perpetrators through hacking into the company's information systems versus other types of breaches. By comparing the two curves, we can see a significant separation between the curves, and we tested the difference between the two using the log-rank test. The test resulted in an insignificant chi-square, which yields to the rejection

Figure 1. Kaplan-Meier Plot for breaches before and after 2018

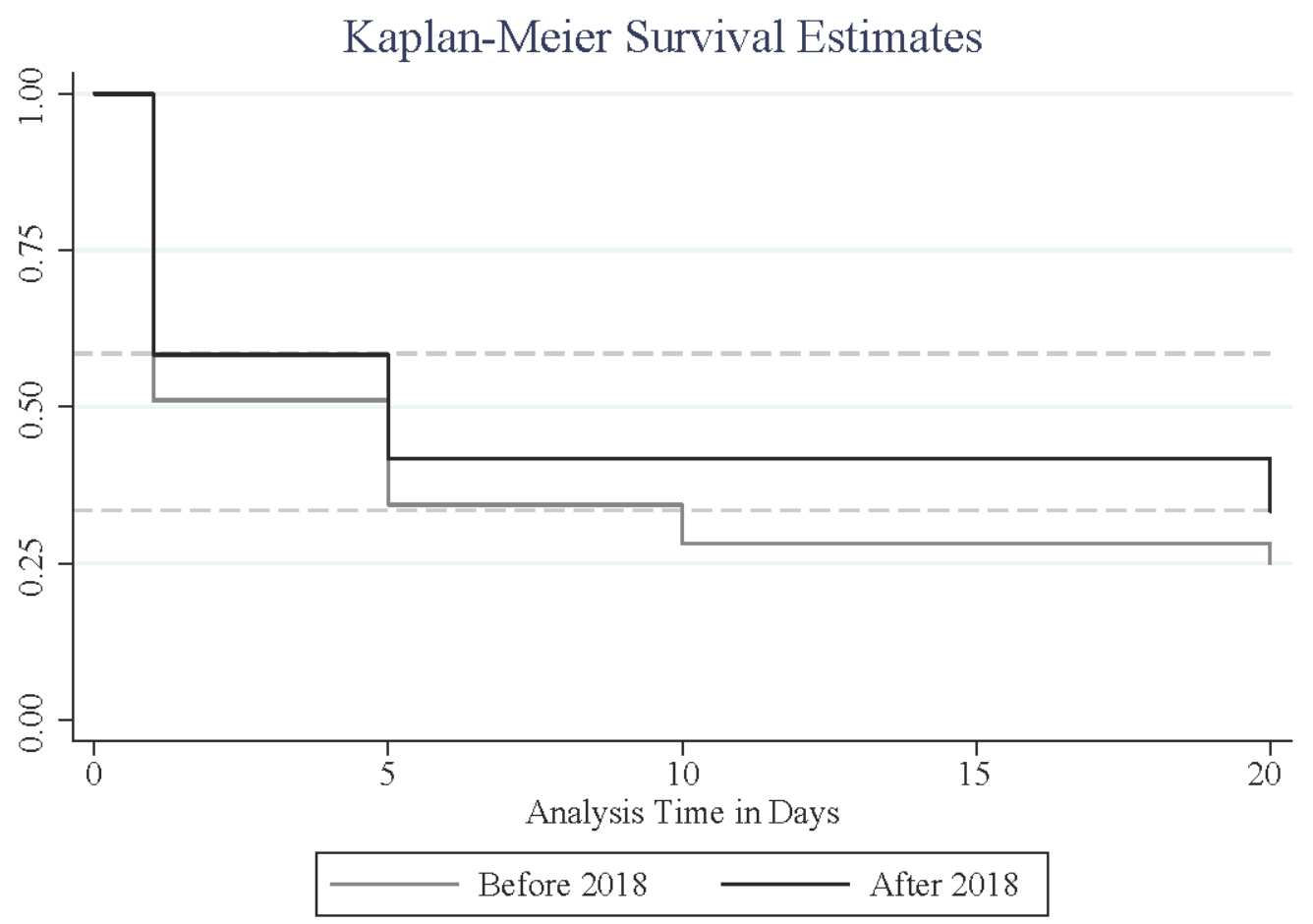

of the null hypothesis that indicates that the two curves are equal. We can also observe from Figure 2 that by the end of the observation window, $30.5 \%$ of the companies that were hacked were yet to reach a positive cumulative return in comparison to $23.5 \%$ of the companies that suffered other types 
of breaches; this is consistent with hypothesis 4 . However, most of the companies reached a positive cumulative return from the breach event within a window of 5 days.

Figure 3 shows the two K-M curves of the breaches there were disclosed by the companies in their financial statements versus the ones that did not. By comparing the two curves, we can see a significant separation between the curves, and we tested the difference between the two curves using the log-rank test. The test showed an insignificant chi-square, which means that the null hypothesis

Figure 2. Kaplan-Meier Plot for breaches by an external perpetrator (hack) vs. other types

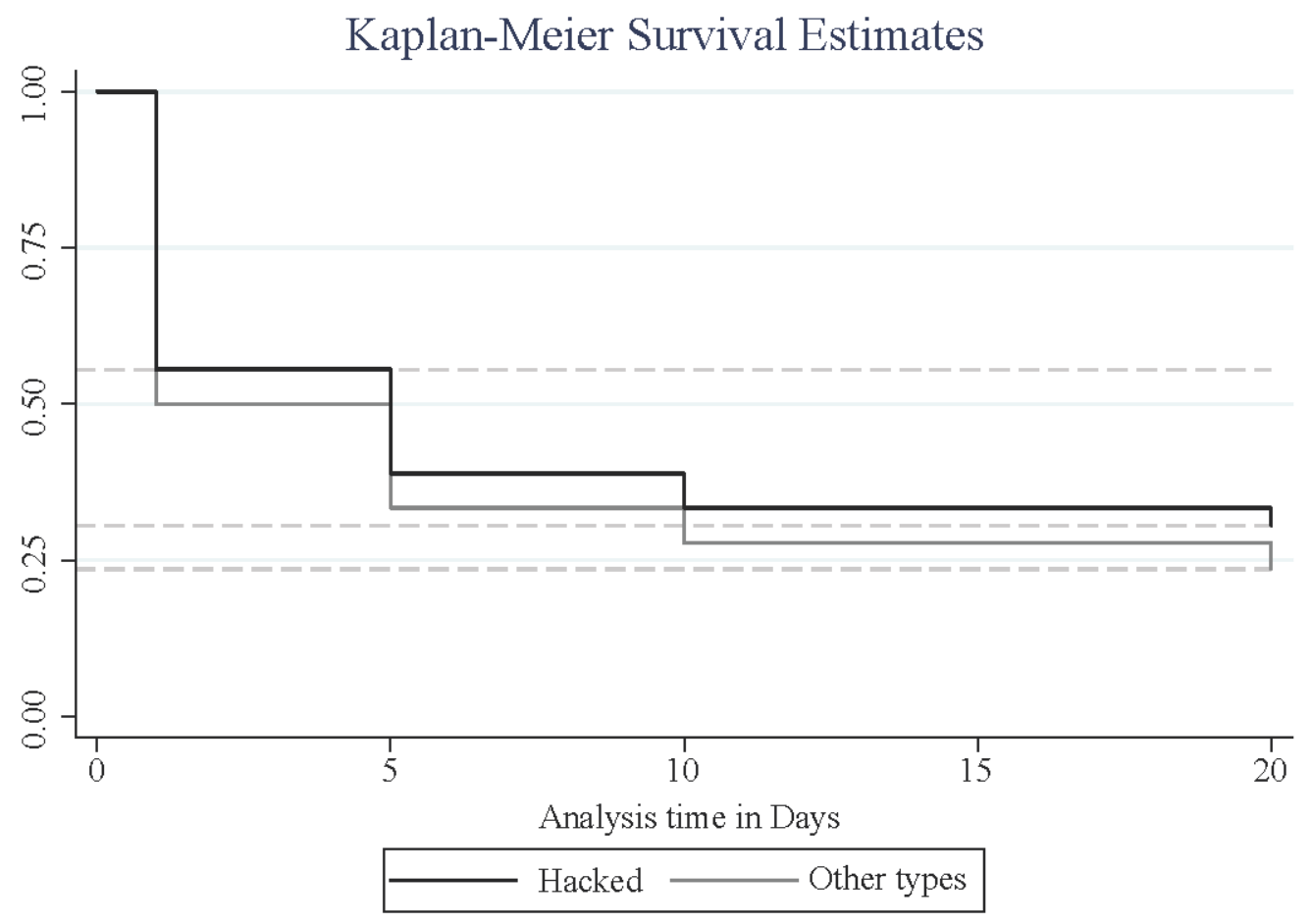

that indicates that the two curves are equal is rejected. We can also notice from Figure 3 that by the end of the observation window, approximately $39.99 \%$ of the companies that disclosed breaches in their financial statements were yet to reach a positive cumulative return in comparison to $23.6 \%$ of the companies that didn't disclose the breach in their financial statements. Also, most of the companies that didn't disclose the breach reached a positive cumulative return from the breach event within a window of 5 days in comparison to a window of 10 days for the companies that disclosed the breach. These results confirm that management considers the materiality of data breach events that influences investors' perceptions regarding the firm's CERs.

\section{CONCLUSION}

This article discusses previous research and bridges the existing research gap regarding the effect of data breach materiality on firms' CERs. Firms invest in information systems and human resources to safeguard 


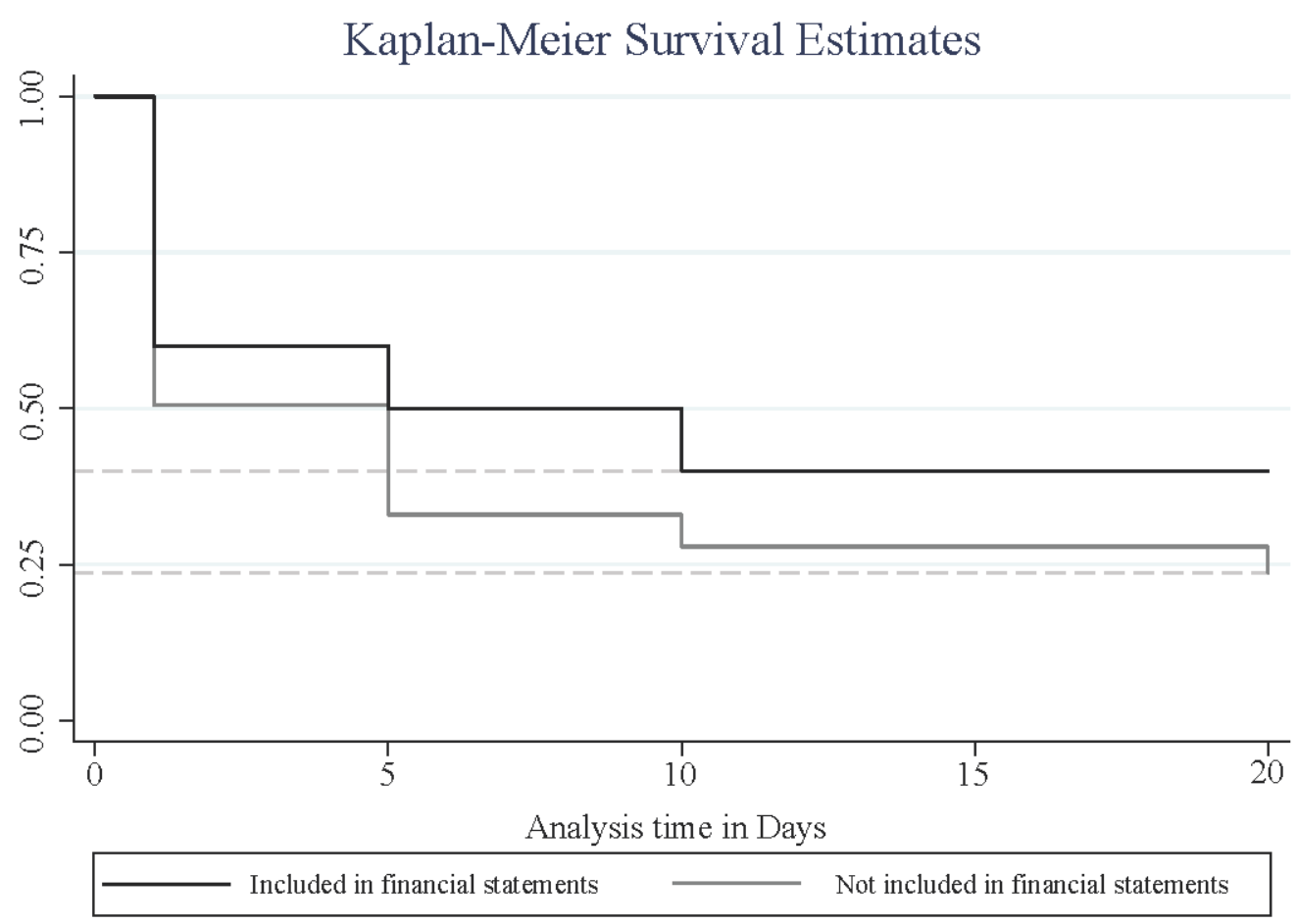

their data and prevent unauthorized use or access to it. Moreover, firms strengthen IS internal controls to minimize breaches due to human behavior and avoid manipulation of data by unauthorized users (such as employees, customers, and other related parties) to comply with applicable regulations and laws.

Our results confirm that investors react negatively to material data breach incidents. The regression results show that the negative effects of data breaches perceived by the stock market are related to the number of affected records. Also, we found that investors react negatively to companies reporting internal control deficiencies in the management report more than companies that do not. Using time-to-event analysis, we noted that the negative perception of investors decreases over a longer period. This is perhaps because management informs stakeholders about the adopted new policies to prevent future data breaches and to protect stakeholders' information. In summary, the main factors that affect investor perception are the affected number of records, external breaches, reporting how a company deals with such incidents, and breaches that occurred after SEC (2018) guidance.

According to the data results, company size, data breach type, year effect, and industry effect are not significant determinants of the severity of the data breach effect on ERs. Moreover, no significant results were found for comparing the first event (single event) with repeated ones (multiple events). However, there are some insights regarding company age and systematic risk. The multivariate regression and timeto-event results give additional insights regarding the intermediate negative effect on company share prices. The number of records is a determinant factor regarding the duration of the data breach effect for about one month after the event day. The results also support the conclusion that the information included in the note of the financial statements of affected companies is correlated with the number of affected records. However, companies that considered contingent liabilities from data breach incidents were more likely to be reporting on class action litigation and possible court outcomes. 


\section{Practical and Theoretical Implications}

There are several practical and theoretical implications of this study. First, information released voluntarily by companies regarding data breach and cybersecurity incidents can be considered as a signal of the companies' performance, which supports the argument that nonmandatory information can assist stakeholders in determining the effect of events on companies' performance and is consistent with the assumption regarding stock market efficiency in the United States. Second, accounting standards are the basis for accountants and management to inform investors about breaches. Our findings can provide accounting setters and policymakers with important clues on the regulation of security and data breachesspecifically, rules related to the reconsideration of the materiality concept in general and concerning data breaches and what breaches management informs investors and when this information occurs. Third, accountants need to consider all obligations from data breach incidents and apply the SEC guidance to inform stakeholders. Managers might consider our findings informative, specifically regarding reporting material breaches in the notes of the financial statements. Also, we recommend comparing the financial notes before and after the SEC 2018 interpretation of its 2011 guidance of companies affected by data breach incidents. Fourth, external, internal, and IT auditors should consider additional steps to ensure that companies are complying with the SEC requirements. Investors not only blame management for not reporting material events, but they might also blame auditors for not testing events that affect the risk factors of an entity. With respect to the efficient market hypothesis, at least in the semi-strong form, investors react negatively to announcements of material cybersecurity attacks. Our study confirms that the efficient market hypothesis is sufficiently valid to provide a practical framework for studying the behavior of share prices regarding announcements of cybersecurity attacks.

\section{Limitations and Further Research}

The main limitation of our study relates to reported information in the financial statements. The consistency or reliability of such information is a matter of judgment. Companies use different accounting treatments, estimations, and decisions to report their financial results. The reported financial variables are mere proxies of the company's realities, but these variables give insights into the effect of cybersecurity on investors' perceptions.

Although the size of our sample is relatively large compared to previous studies, it was not large enough to segregate the sample to explore more issues regarding data breach announcements using quantitative and qualitative factors. Also, the identification of major confounding events is not an easy task, and this is a common limitation for event study methods. We tried to identify these events around the date of the event date, but this is not an assurance that other events might exist, and this is beyond any research's generalization of results. Therefore, we recommend replicating the research when more breaches occur that might enable aggrupation of the data based on industry classification.

We recommend further studies to associate the company's risk for data breaches with systematic or nonsystematic risk characterizations. In the long run, firms that experience data breach incidents may suffer from weakened reputations and a deterioration in stakeholders' trust, and, consequently, a decline in revenue. Proxies to explore the effect of data breach announcements in the long term include trends in sales revenue, net profits before and after the announcements, and any long-term liability that occurs from a legal consequence of the event. A firm strikes a balance between producing and protecting an information set, dependent on seven model parameters for production, protection, convexity, concavity, vulnerability, and resource strength (Hausken, 2014). Therefore, we recommend studying the determinants that influence the companies that face long-term negative effects. 


\section{REFERENCES}

Acquisti, A., Brandimarte, L., \& Loewenstein, G. (2018). Privacy and Human Behavior in the Information Age. The Cambridge Handbook of Consumer Privacy, 184. doi:10.1017/9781316831960.010

Acquisti, A., Friedman, A., \& Telang, R. (2006). Is there a cost to privacy breaches? An event study. ICIS 2006 Proceedings, 94.

Acquisti, A., John, L. K., \& Loewenstein, G. (2013). What is privacy worth? The Journal of Legal Studies, 42(2), 249-274. doi:10.1086/671754

Ayyagari, R. (2012). An exploratory analysis of data breaches from 2005-2011: Trends and insights. Journal of Information Privacy and Security, 8(2), 33-56. doi:10.1080/15536548.2012.10845654

Bandyopadhyay, T., Liu, D., Mookerjee, V. S., \& Wilhite, A. W. (2014). Dynamic competition in IT security: A differential games approach. Information Systems Frontiers, 16(4), 643-661. doi:10.1007/s10796-012-9373-x

Benaroch, M., Chernobai, A., \& Goldstein, J. (2012). An internal control perspective on the market value consequences of IT operational risk events. International Journal of Accounting Information Systems, 13(4), 357-381. doi:10.1016/j.accinf.2012.03.001

Bernardi, R. A., \& Pincus, K. V. (1996). The relationship between materiality thresholds and judgments of fraud risk. Managerial Finance, 22(9), 1-15. doi:10.1108/eb018578

Binder, J. J. (1985). Measuring the effects of regulation with stock price data. The RAND Journal of Economics, 16(2), 167-183. doi:10.2307/2555408

Black, F. (1972). Capital market equilibrium with restricted borrowing. The Journal of Business, 45(3), 444-455. doi: $10.1086 / 295472$

Boatsman, J. R., \& Robertson, J. C. (1974). Policy-capturing on selected materiality judgments. The Accounting Review, 49(2), 342-352.

Bolster, P., Pantalone, C. H., \& Trahan, E. A. (2010). Security breaches and firm value. Journal of Business Valuation and Economic Loss Analysis, 5(1). Advance online publication. doi:10.2202/1932-9156.1081

Bose, I., \& Leung, A. C. M. (2013). The impact of adoption of identity theft countermeasures on firm value. Decision Support Systems, 55(3), 753-763. doi:10.1016/j.dss.2013.03.001

Brown, S. J., \& Warner, J. B. (1980). Measuring security price performance. Journal of Financial Economics, 8(3), 205-258. doi:10.1016/0304-405X(80)90002-1

Brown, S. J., \& Warner, J. B. (1985). Using daily stock returns: The case of event studies. Journal of Financial Economics, 14(1), 3-31. doi:10.1016/0304-405X(85)90042-X

Campbell, K., Gordon, L. A., Loeb, M. P., \& Zhou, L. (2003). The economic cost of publicly announced information security breaches: Empirical evidence from the stock market. Journal of Computer Security, 11(3), 431-448. doi:10.3233/JCS-2003-11308

Cavusoglu, H., Mishra, B., \& Raghunathan, S. (2004). The effect of internet security breach announcements on market value: Capital market reactions for breached firms and internet security developers. International Journal of Electronic Commerce, 9(1), 70-104. doi:10.1080/10864415.2004.11044320

Cavusoglu, H., Mishra, B., \& Raghunathan, S. (2005). The value of intrusion detection systems in information technology security architecture. Information Systems Research, 16(1), 28-46. doi:10.1287/isre.1050.0041

Chatterjee, D., Kumar, S., \& Chatterjee, P. (2019). Time to Payoff: Efficacy of Analyst Recommendations in the Indian Stock Market. IIMB Management Review. Advance online publication. doi:10.1016/j.iimb.2019.10.002

Chatterjee, S., Gao, X., Sarkar, S., \& Uzmanoglu, C. (2019). Reacting to the scope of a data breach: The differential role of fear and anger. Journal of Business Research, 101, 183-193. doi:10.1016/j.jbusres.2019.04.024

Chen, P. S., Yen, D. C., \& Lin, S.-C. (2015). The Classification of Information Assets and Risk Assessment: An Exploratory Study using the Case of C-Bank. Journal of Global Information Management, 23(4), 26-54. doi:10.4018/JGIM.2015100102 
Deane, J. K., Goldberg, D. M., Rakes, T. R., \& Rees, L. P. (2019). The effect of information security certification announcements on the market value of the firm. Information Technology Management, 20(3), 107-121. doi:10.1007/s10799-018-00297-3

DeZoort, F. T., Holt, T. P., \& Stanley, J. D. (2019). A comparative analysis of investor and auditor materiality judgments. Auditing, 38(3), 149-166. doi:10.2308/ajpt-52318

Dinev, T., Bellotto, M., Hart, P., Russo, V., \& Serra, I. (2006). Internet users' privacy concerns and beliefs about government surveillance: An exploratory study of differences between Italy and the United States. Journal of Global Information Management, 14(4), 57-93. doi:10.4018/jgim.2006100103

Efron, B. (1988). Logistic regression, survival analysis, and the Kaplan-Meier curve. Journal of the American Statistical Association, 83(402), 414-425. doi:10.1080/01621459.1988.10478612

Ettredge, M. L., \& Richardson, V. J. (2003). Information transfer among internet firms: The case of hacker attacks. Journal of Information Systems, 17(2), 71-82. doi:10.2308/jis.2003.17.2.71

Fama, E. F. (1970). Efficient capital markets: A review of theory and empirical work. The Journal of Finance, 25(2), 383-417. doi:10.2307/2325486

Fama, E. F., \& French, K. R. (2016). Commodity futures prices: Some evidence on forecast power, premiums, and the theory of storage. In The World Scientific Handbook Of Futures Markets (pp. 79-102). World Scientific.

Fama, E. F., \& French, K. R. (2017). International tests of a five-factor asset pricing model. Journal of Financial Economics, 123(3), 441-463. doi:10.1016/j.jfineco.2016.11.004

Fama, E. F., \& French, K. R. (2018). Choosing factors. Journal of Financial Economics, 128(2), $234-252$. doi:10.1016/j.jfineco.2018.02.012

Fama, E. F., \& Miller, M. H. (1972). The theory of finance. Holt Rinehart \& Winston.

Feroz, E. H., Park, K., \& Pastena, V. S. (1991). The financial and market effects of the SEC's accounting and auditing enforcement releases. Journal of Accounting Research, 29, 107-142. doi:10.2307/2491006

Fotiadis, A., \& Yu, H. (2019). Prospectus and limitations of algorithmic governance: An ecological evaluation of algorithmic trends. Digital Policy. Regulation \& Governance, 24(4), 369-383. doi:10.1108/DPRG-03-2019-0017

Garg, A., Curtis, J., \& Halper, H. (2003). Quantifying the financial impact of IT security breaches. Information Management \& Computer Security, 11(2), 74-83. doi:10.1108/09685220310468646

Gatzlaff, K. M., \& McCullough, K. A. (2010). The effect of data breaches on shareholder wealth. Risk Management \& Insurance Review, 13(1), 61-83. doi:10.1111/j.1540-6296.2010.01178.x

George, B., Seals, S., \& Aban, I. (2014). Survival analysis and regression models. Journal of Nuclear Cardiology, 21(4), 686-694. doi:10.1007/s12350-014-9908-2 PMID:24810431

Goel, S., \& Shawky, H. A. (2009). Estimating the market impact of security breach announcements on firm values. Information \& Management, 46(7), 404-410. doi:10.1016/j.im.2009.06.005

Goldstein, J., Chernobai, A., \& Benaroch, M. (2011). An event study analysis of the economic impact of IT operational risk and its subcategories. Journal of the Association for Information Systems, $12(9), 1$. doi:10.17705/1jais.00275

Gordon, L. A., \& Loeb, M. P. (2002). The economics of information security investment. ACM Transactions on Information and System Security, 5(4), 438-457. doi:10.1145/581271.581274

Gordon, L. A., Loeb, M. P., \& Sohail, T. (2010). Market value of voluntary disclosures concerning information security. Management Information Systems Quarterly, 34(3), 567-594. doi:10.2307/25750692

Gordon, L. A., Loeb, M. P., \& Zhou, L. (2011). The impact of information security breaches: Has there been a downward shift in costs? Journal of Computer Security, 19(1), 33-56. doi:10.3233/JCS-2009-0398

Greene, W. H. (2012). Econometric analysis, 71e. Stern School of Business, New York University.

Harrell, F. E. (2015). Introduction to survival analysis. In Regression Modeling Strategies (pp. 399-422). Springer. doi:10.1007/978-3-319-19425-7_17 
Harris, K. D. (2016). California Data California Data Breach Report. https://oag.ca.gov/sites/all/files/agweb/ pdfs/dbr/2016-data-breach-report.pdf

Hausken, K. (2014). Returns to information security investment: Endogenizing the expected loss. Information Systems Frontiers, 16(2), 329-336. doi:10.1007/s10796-012-9390-9

He, W., \& Zhang, Z. (2019). Enterprise cybersecurity training and awareness programs: Recommendations for success. Journal of Organizational Computing and Electronic Commerce, 29(4), 249-257. doi:10.1080/1091 9392.2019.1611528

Hooker, M., \& Pill, J. (2016). You've Been Hacked, and Now You're Being Sued: The Developing World of Cybersecurity Litigation. The Florida Bar Journal, 31.

Hovav, A., \& D'Arcy, J. (2003). The impact of denial-of-service attack announcements on the market value of firms. Risk Management \& Insurance Review, 6(2), 97-121. doi:10.1046/J.1098-1616.2003.026.x

Hovav, A., \& D'Arcy, J. (2004). The impact of virus attack announcements on the market value of firms. Information Systems Security, 13(3), 32-40. doi:10.1201/1086/44530.13.3.20040701/83067.5

Huang, M. Y., Rojas, R. R., \& Convery, P. D. (2019). Forecasting stock market movements using Google Trend searches. Empirical Economics, 1-19.

Juma'h, A. H. (2014). The Materiality Concept: Implications for Managers and Investors. Revista Finanzas y Política Económica, 6(1), 159-168. doi:10.14718/revfinanzpolitecon.2014.6.1.8

Kannan, K., Rees, J., \& Sridhar, S. (2007). Market reactions to information security breach announcements: An empirical analysis. International Journal of Electronic Commerce, 12(1), 69-91. doi:10.2753/JEC10864415120103

Karafiath, I. (1988). Using dummy variables in the event methodology. Financial Review, 23(3), 351-357. doi:10.1111/j.1540-6288.1988.tb01273.x

Kokolakis, S. (2017). Privacy attitudes and privacy behaviour: A review of current research on the privacy paradox phenomenon. Computers \& Security, 64, 122-134. doi:10.1016/j.cose.2015.07.002

Lawrence, A., Minutti-Meza, M., \& Vyas, D. (2018). Is operational control risk informative of financial reporting deficiencies? Auditing, 37(1), 139-165. doi:10.2308/ajpt-51784

Leung, A., \& Bose, I. (2008). Indirect financial loss of phishing to global market. ICIS 2008 Proceedings, 5.

Li, L., He, W., Xu, L., Ash, I., Anwar, M., \& Yuan, X. (2019). Investigating the impact of cybersecurity policy awareness on employees' cybersecurity behavior. International Journal of Information Management, 45, 13-24. doi:10.1016/j.ijinfomgt.2018.10.017

Lintner, J. (1965). Security prices, risk, and maximal gains from diversification. The Journal of Finance, 20(4), $587-615$.

Lyu, H., \& Zhang, Z. (2015). Job quitters, information security awareness, and knowledge management strategies. Journal of Information Privacy and Security, 11(4), 189-210. doi:10.1080/15536548.2015.1105594

MacKinlay, A. C. (1997). Event studies in economics and finance. Journal of Economic Literature, 35(1), 13-39.

Malhotra, A., \& Kubowicz Malhotra, C. (2011). Evaluating customer information breaches as service failures: An event study approach. Journal of Service Research, 14(1), 44-59. doi:10.1177/1094670510383409

Martin, K. D., Borah, A., \& Palmatier, R. W. (2017). Data privacy: Effects on customer and firm performance. Journal of Marketing, 81(1), 36-58. doi:10.1509/jm.15.0497

Moroney, R., \& Trotman, K. T. (2016). Differences in auditors' materiality assessments when auditing financial statements and sustainability reports. Contemporary Accounting Research, 33(2), 551-575. doi:10.1111/19113846.12162

Nofer, M. (2015). The Economic Impact of Privacy Violations and Security Breaches-A Laboratory Experiment. In The Value of Social Media for Predicting Stock Returns (pp. 89-108). Springer. doi:10.1007/978-3-65809508-6_5 
Nofer, M., Hinz, O., Muntermann, J., \& Roßnagel, H. (2014). The economic impact of privacy violations and security breaches. Business \& Information Systems Engineering, 6(6), 339-348. doi:10.1007/s12599-014-0351-3

Park, Y. J., \& Shin, D. D. (2020). Contextualizing privacy on health-related use of information technology. Computers in Human Behavior, 105, 106204. doi:10.1016/j.chb.2019.106204

Park, Y. J., Chung, J. E., \& Shin, D. H. (2018). The structuration of digital ecosystem, privacy, and big data intelligence. The American Behavioral Scientist, 62(10), 1319-1337. doi:10.1177/0002764218787863

Patel, N. (2010). The effect of IT hack announcements on the market value of publicly traded corporations. Duke J Econ, 22.

Patell, J. M. (1976). Corporate forecasts of earnings per share and stock price behavior: Empirical test. Journal of Accounting Research, 14(2), 246-276. doi:10.2307/2490543

Piercey, M. D. (2009). Motivated reasoning and verbal vs. numerical probability assessment: Evidence from an accounting context. Organizational Behavior and Human Decision Processes, 108(2), 330-341. doi:10.1016/j. obhdp.2008.05.004

Png, I. P., Wang, C.-Y., \& Wang, Q.-H. (2008). The deterrent and displacement effects of information security enforcement: International evidence. Journal of Management Information Systems, 25(2), 125-144. doi:10.2753/ MIS0742-1222250206

Rao, S. J. (2003). Regression modeling strategies: with applications to linear models, logistic regression, and survival analysis. Taylor \& Francis.

Ribeiro, J. (2017). Business Survival Analysis Using SAS: An Introduction to Lifetime Probabilities. Sas Institute.

Richardson, R., \& Director, C. (2008). CSI computer crime and security survey. Computer Security Institute.

Richardson, V. J., Smith, R. E., \& Watson, M. W. (2019). Much ado about nothing: The (lack of) economic impact of data privacy breaches. Journal of Information Systems, 33(3), 227-265. doi:10.2308/isys-52379

Romanosky, S., Telang, R., \& Acquisti, A. (2011). Do data breach disclosure laws reduce identity theft? Journal of Policy Analysis and Management, 30(2), 256-286. doi:10.1002/pam.20567

Rosati, P., Cummins, M., Deeney, P., Gogolin, F., van der Werff, L., \& Lynn, T. (2017). The effect of data breach announcements beyond the stock price: Empirical evidence on market activity. International Review of Financial Analysis, 49, 146-154. doi:10.1016/j.irfa.2017.01.001

Rosati, P., Deeney, P., Cummins, M., Van der Werff, L., \& Lynn, T. (2018). Should You Disclose a Data Breach via Social Media? Evidence from US Listed Companies. Proceedings of the 51st Hawaii International Conference on System Sciences.

Rosati, P., Deeney, P., Cummins, M., Van der Werff, L., \& Lynn, T. (2019). Social media and stock price reaction to data breach announcements: Evidence from US listed companies. Research in International Business and Finance, 47, 458-469. doi:10.1016/j.ribaf.2018.09.007

Salinger, M. (1992). Standard errors in event studies. Journal of Financial and Quantitative Analysis, 27(1), 39-53. doi: $10.2307 / 2331297$

Schatz, D., \& Bashroush, R. (2016). The impact of repeated data breach events on organisations' market value. Information \& Computer Security, 24(1), 73-92. doi:10.1108/ICS-03-2014-0020

Schlosser, A. E., White, T. B., \& Lloyd, S. M. (2006). Converting web site visitors into buyers: How web site investment increases consumer trusting beliefs and online purchase intentions. Journal of Marketing, 70(2), 133-148. doi:10.1509/jmkg.70.2.133

Schmidt, M. B., Johnston, A. C., Arnett, K. P., Chen, J. Q., \& Li, S. (2008). A cross-cultural comparison of US and Chinese computer security awareness. Journal of Global Information Management, 16(2), 91-103. doi:10.4018/jgim.2008040106

Securities and Exchange Commission (SEC) (1999). SEC Staff Accounting Bulletin: No. 99-Materiality. Author. 
Securities and Exchange Commission (SEC). (2003). SEC Implements Internal Control Provisions of SarbanesOxley Act; Adopts Investment Company R\&D Safe Harbor. Washington, DC: SEC. Available at: https://www. sec.gov/news/press/2003-66.htm

Securities and Exchange Commission (SEC). (2005). Staff Statement on Management's Report on Internal Control Over Financial Reporting. SEC.

Securities and Exchange Commission (SEC). (2011). CF Disclosure Guidance: Topic No. 2 Cybersecurity. US Securities and Exchange Commission.

Securities and Exchange Commission (SEC). (2011). CF Disclosure Guidance: Topic No. 2-Cybersecurity. SEC.

Securities and Exchange Commission (SEC). (2017). Statement on Cybersecurity by Chairman Jay Clayton. Washington, DC: SEC. Available at: https://www.sec.gov/news/public-statement/statement-clayton-2017-09-20

Sen, R., \& Borle, S. (2015). Estimating the contextual risk of data breach: An empirical approach. Journal of Management Information Systems, 32(2), 314-341. doi:10.1080/07421222.2015.1063315

Shabtai, A., Elovici, Y., \& Rokach, L. (2012). A survey of data leakage detection and prevention solutions. Springer Science \& Business Media. doi:10.1007/978-1-4614-2053-8

Sharpe, W. F. (1964). Capital asset prices: A theory of market equilibrium under conditions of risk. The Journal of Finance, 19(3), 425-442.

Shin, D. D., Fotiadis, A., \& Yu, H. (2019). Prospectus and limitations of algorithmic governance: an ecological evaluation of algorithmic trends. Digital Policy, Regulation and Governance.

Shin, D.-H. (2010). The effects of trust, security and privacy in social networking: A security-based approach to understand the pattern of adoption. Interacting with Computers, 22(5), 428-438. doi:10.1016/j.intcom.2010.05.001

Tan, H.-T., \& Yu, Y. (2018). Management's responsibility acceptance, locus of breach, and investors' reactions to internal control reports. The Accounting Review, 93(6), 331-355. doi:10.2308/accr-52077

Teh, P.-L., Ahmed, P. K., \& D’Arcy, J. (2015). What drives information security policy violations among banking employees?: Insights from neutralization and social exchange theory. Journal of Global Information Management, 23(1), 44-64. doi:10.4018/jgim.2015010103

Ting, S. H. (2012). Prediction of Likelihood of Failure of Underground Linear Assets Using Survival Analysis. Oklahoma State University.

Tucker, A. L. (1994). Contemporary portfolio theory and risk management. West Publishing Company.

Tweneboah-Kodua, S., Atsu, F., \& Buchanan, W. (2018). Impact of cyberattacks on stock performance: a comparative study. Information \& Computer Security.

Van den Poel, D., \& Lariviere, B. (2004). Customer attrition analysis for financial services using proportional hazard models. European Journal of Operational Research, 157(1), 196-217. doi:10.1016/S0377-2217(03)000699

van Driel, H. (2019). Financial fraud, scandals, and regulation: A conceptual framework and literature review. Business History, 61(8), 1259-1299. doi:10.1080/00076791.2018.1519026

Wang, J., Faridani, S., \& Ipeirotis, P. (2011). Estimating the completion time of crowdsourced tasks using survival analysis models. Crowdsourcing for search and data mining (CSDM 2011), 31, 31-38.

Wang, P. (2010). Chasing the hottest IT: Effects of information technology fashion on organizations. Management Information Systems Quarterly, 34(1), 63-85. doi:10.2307/20721415

Wang, Q., \& Ngai, E. (2018). Resource-based Perspective on Slack and Data Breach. Academic Press.

Xu, F., Luo, X. R., Zhang, H., Liu, S., \& Huang, W. W. (2017). Do Strategy and Timing in IT Security Investments Matter? An Empirical Investigation of the Alignment Effect. Information Systems Frontiers, 1-15.

Yaokumah, W., Walker, D. O., \& Kumah, P. (2019). SETA and Security Behavior: Mediating Role of Employee Relations, Monitoring, and Accountability. Journal of Global Information Management, 27(2), 102-121. doi:10.4018/JGIM.2019040106 
Yayla, A. A., \& Hu, Q. (2011). The impact of information security events on the stock value of firms: The effect of contingency factors. Journal of Information Technology, 26(1), 60-77. doi:10.1057/jit.2010.4

Zafar, H., Ko, M. S., \& Osei-Bryson, K.-M. (2016). The value of the CIO in the top management team on performance in the case of information security breaches. Information Systems Frontiers, 18(6), 1205-1215. doi:10.1007/s10796-015-9562-5 


\section{APPENDIX I.}

\section{Characteristic of The Data Breach Sample}

Table 5. Annual distribution of data breach announcements

\begin{tabular}{|l|l|l|l|}
\hline \multicolumn{1}{|c|}{ Year } & \multicolumn{1}{|c|}{$\begin{array}{c}\text { Number of data } \\
\text { breach announcements }\end{array}$} & \multicolumn{1}{c|}{$\begin{array}{c}\text { Percentage of all } \\
\text { announcements }\end{array}$} & \multicolumn{1}{c|}{ of announcements } \\
\hline 2005 & 9 & $4 \%$ & 9 \\
\hline 2006 & 23 & $10 \%$ & 32 \\
\hline 2007 & 22 & $9 \%$ & 54 \\
\hline 2008 & 12 & $5 \%$ & 66 \\
\hline 2009 & 6 & $3 \%$ & 72 \\
\hline 2010 & 21 & $9 \%$ & 93 \\
\hline 2011 & 13 & $6 \%$ & 106 \\
\hline 2012 & 16 & $7 \%$ & 122 \\
\hline 2013 & 19 & $8 \%$ & 141 \\
\hline 2014 & 31 & $13 \%$ & 172 \\
\hline 2015 & 3 & $6 \%$ & 185 \\
\hline 2016 & 10 & $4 \%$ & 195 \\
\hline 2017 & 16 & $7 \%$ & 211 \\
\hline 2018 & 21 & $9 \%$ & 232 \\
\hline Total & 232 & 100 & - \\
\hline & & & \\
\hline
\end{tabular}


Table 6. Sample composition

\begin{tabular}{|c|c|c|c|c|}
\hline Sector (naics) & $\begin{array}{l}\text { Number of } \\
\text { companies }\end{array}$ & $\begin{array}{l}\text { Percentage of } \\
\text { companies }\end{array}$ & $\begin{array}{l}\text { Number of } \\
\text { events }\end{array}$ & $\begin{array}{l}\text { Percentage of } \\
\text { events }\end{array}$ \\
\hline $\begin{array}{l}\text { Mining, quarrying, and oil } \\
\text { and gas extraxtion } 21\end{array}$ & 2 & $1.52 \%$ & 2 & $0.86 \%$ \\
\hline Utilitis 22 & 1 & $0.76 \%$ & 1 & $0.43 \%$ \\
\hline Manufacuring 31 & 2 & $1.52 \%$ & 5 & $2.16 \%$ \\
\hline Manufacuring 32 & 5 & $3.79 \%$ & 7 & $3.02 \%$ \\
\hline Manufacuring 33 & 18 & $13.64 \%$ & 32 & $1379 \%$ \\
\hline Wholesae Trade 42 & 1 & $0.76 \%$ & 1 & $0.43 \%$ \\
\hline Retail rade 44 & 6 & $4.55 \%$ & 15 & $6.47 \%$ \\
\hline Retail rade 45 & 5 & $3.79 \%$ & 9 & $3.88 \%$ \\
\hline $\begin{array}{l}\text { Transpotation and } \\
\text { warehousing } 48\end{array}$ & 4 & $3.03 \%$ & 4 & $1.72 \%$ \\
\hline $\begin{array}{l}\text { Transpotation and } \\
\text { warehousing } 49\end{array}$ & 2 & $1.52 \%$ & 10 & $4.31 \%$ \\
\hline Informaion 51 & 11 & $8.33 \%$ & 15 & $6.47 \%$ \\
\hline Financeand insurance 52 & 44 & $33.33 \%$ & 87 & $3750 \%$ \\
\hline $\begin{array}{l}\text { Real stte and rental and } \\
\text { leasing } 53\end{array}$ & 1 & $0.76 \%$ & 1 & $0.43 \%$ \\
\hline $\begin{array}{l}\text { Professonal, scientific, } \\
\text { technical services } 54\end{array}$ & 9 & $6.82 \%$ & 10 & $4.31 \%$ \\
\hline $\begin{array}{l}\text { Adminisrative and support } \\
\text { and waste management } 56\end{array}$ & 6 & $4.55 \%$ & 10 & $4.31 \%$ \\
\hline Educatinal services 61 & 1 & $0.76 \%$ & 1 & $0.43 \%$ \\
\hline $\begin{array}{l}\text { Health are and social } \\
\text { assistance } 62\end{array}$ & 6 & $4.55 \%$ & 13 & $5.60 \%$ \\
\hline $\begin{array}{l}\text { Accommoation and food } \\
\text { services } 72\end{array}$ & 8 & $6.06 \%$ & 9 & $3.88 \%$ \\
\hline Total & 132 & $100.00 \%$ & 232 & $100.00 \%$ \\
\hline
\end{tabular}

\section{APPENDIX II.}

Table 7. Description of data breach types

\begin{tabular}{|c|c|c|c|c|c|c|c|}
\hline \multicolumn{2}{|r|}{ Type of breach } & \multirow{2}{*}{$\begin{array}{c}\text { Frequency } \\
24\end{array}$} & \multirow{2}{*}{$\frac{\%}{8.11 \%}$} & \multicolumn{2}{|c|}{ Type of breach } & \multirow{2}{*}{$\begin{array}{c}\text { Frequency } \\
6\end{array}$} & \multirow{2}{*}{$\frac{\%}{2.03 \%}$} \\
\hline Insd & Insider & & & Stat & Stationry device & & \\
\hline Port & ortabl device & 46 & $15.54 \%$ & Hack & Hackingor malware & 56 & $18.92 \%$ \\
\hline Unkn & Unknown & 12 & $4.05 \%$ & Card & Paymentcard fraud & 4 & $1.35 \%$ \\
\hline \multirow[t]{2}{*}{ Disc } & nintened disclosure & 52 & $17.57 \%$ & Phys & Physica loss & 32 & $10.81 \%$ \\
\hline & & & & Total & & 232 & $100 \%$ \\
\hline
\end{tabular}




\section{Event Study Methodology}

The event study method is frequently used in economics, finance, accounting, and information management to evaluate the effect of an event on a company's stock values. Ashley (1962), Dolley (1933), and Myers and Bakay (1948) were among the pioneers of this technique. The event study methodology was further refined by Ball and Brown (1968) and Fama et al. (1969), and their approach provided the foundation for many studies that linked a specific event to a company's performance and assuming the semistrong form of the efficient capital market (Fama, 1970; Fama \& French, 2016). The event study methodology was further extended by (Binder, 1985) by incorporating multivariate analysis to explain abnormal returns associated with an event. Many scholars provided useful reviews of the standard event study methodology (Brown \& Warner, 1980, 1985; Karafiath, 1988; MacKinlay, 1997; Patell, 1976; Salinger, 1992), and of survival analysis (Efron, 1988; Van den Poel \& Lariviere, 2004; Wang et al., 2011; Huang et al., 2019).

We consider the definition of returns regarding sample companies $\left(R_{j}\right)$ and market returns $\left(R_{m}\right)$ as $\mathrm{R}_{\mathrm{jt}}=\mathrm{P}_{\mathrm{jt}} / \mathrm{P}_{\mathrm{jt}-1}-1 ; \mathrm{R}_{\mathrm{mt}}=\mathrm{P}_{\mathrm{mt}} / \mathrm{P}_{\mathrm{mt}-1}-1$, where $\mathrm{P}_{\mathrm{jt}}$ and $\mathrm{P}_{\mathrm{jt}-1}$ are the prices of security $\mathrm{j}$ at time $\mathrm{t}$ and $\mathrm{t}_{-1} ; \mathrm{P}_{\mathrm{mt}}$ and $\mathrm{P}_{\mathrm{mt}-1}$ are the prices of the market portfolio at $\mathrm{t}$ and $\mathrm{t}_{-1} ; \mathrm{R}_{\mathrm{jt}}$ and $\mathrm{R}_{\mathrm{mt}}$ are the returns on security $\mathrm{j}$ and the market index proxied by Standard \& Poor's Index; and $\bar{R}=1 / T \sum_{t=1}^{T} R_{. t}$ is the average of stock returns over a return window $(\mathrm{T})$.

Based on conventional event studies, the null hypothesis, $\mathrm{H}_{0}$, tested against the alternative hypothesis, $\mathrm{H}_{\mathrm{a}}$, would show that the mean day $\mathrm{t}_{0}$ excess return (ER) would be equal to zero, and $\mathrm{ER}$ would be significantly different from zero. The four proxies frequently used to estimate expected returns are mean adjusted ER; market-adjusted ER; market risk-adjusted ER (MRAR), using the ordinary least squares (OLS) market model; and the Capital Assets Pricing Model (CAPM). In this article, we use the last two proxies because they incorporate the risk adjustment. The beta and standard deviation of the share prices in the estimation window are used as a proxy for risk. According to Brown and Warner (1985), models incorporating risk are more robust than models using and comparing averages of share prices. The adjustment made here was based on the market model initiated by Black (1972), Lintner (1965), and Sharpe (1964), which specifies a linear ex-ante relation between the return on the shares of the firm $\mathrm{j}$ and the return on the market portfolio with a slope $\beta$. The OLS market model used to estimate ER $\left(\mathrm{ER}_{\mathrm{jj}}\right)$ was $\mathrm{MRA}\left(\mathrm{ER}_{\mathrm{jt}}\right)=\mathrm{R}_{\mathrm{jt}}-\left(\alpha_{\mathrm{j}}+\beta_{\mathrm{j}}{ }^{*} \mathrm{R}_{\mathrm{mt}}\right)$, where $\alpha \mathrm{j}$ and $\beta \mathrm{j}$ are MRAR model parameter estimates obtained by regressing daily returns for security $\mathrm{j}$ on Standard \& Poor's Index over the estimation period (i.e., days -255 to -5 ).

The ER using the CAPM model is CAPM $\left(E R_{j t}\right)=\left(R_{j t}-R_{f t}\right)-\beta_{j}\left(R_{m t}-R_{f t}\right)$, where $\beta$ is obtained from regressing $\left(\mathrm{R}_{\mathrm{jt}}-\mathrm{R}_{\mathrm{ft}}\right)$ on $\left(\mathrm{R}_{\mathrm{mt}}-\mathrm{R}_{\mathrm{ft}}\right)$ for the estimation period and $\mathrm{R}_{\mathrm{ft} t}$ is the estimate of risk-free daily return obtained from the one-month T-Bill return. The test statistic is the ratio of the event day $\mathrm{t}_{0}$ mean ER $\left(\mathrm{MER}_{\mathrm{t}}\right)$ to its estimated standard deviation $\left(\mathrm{S}_{\mathrm{MER}}\right)$, where $M E R_{t}=\sum_{J=1}^{J} E R_{j t} / J$; $S_{M E R t}=\left(\sum_{t=-255}^{-5}\left(\left(M E R_{t}-\overline{M E R}\right)^{2} / 250\right)^{\frac{1}{2}} ; \overline{M E R}=\sum_{-255}^{-5} M E R_{t} / 251\right.$; and Jis the number of data breach events. For testing the ER over length T days, the test statistic is the ratio of the cumulative mean ER (CER) to its estimated standard deviation (Brown \& Warner, 1985; MacKinlay,

1997), $\sum_{t=1}^{T} M E R_{t} /\left(\sum_{t=1}^{T} S_{M E R_{t}}^{2}\right)^{\frac{1}{2}}$. The variance of $\left(\mathrm{MER}_{\mathrm{t}}\right.$ ) for all cumulative intervals is taken from the estimation period and adjusted for different evaluation windows as follows: $\left(\sum_{t=1}^{T} M E R_{t}\right) /\left(T^{0.5} S_{M E R t}\right)$. 
Volume $29 \cdot$ Issue 6

\section{APPENDIX III.}

\section{Correlation and Regression Results}

\section{Table 8. The Pearson correlation coefficient between the selected variables}

\begin{tabular}{|c|c|c|c|c|c|c|c|c|c|c|c|c|c|c|c|c|c|c|c|}
\hline & VVariables & 1 & 2 & 3 & 4 & 5 & 6 & 7 & 8 & 9 & 10 & 11 & 12 & 1 & 14 & 15 & 16 & 17 & 18 \\
\hline 1 & $\mathrm{Ce}\left[\mathrm{t}_{0}\right]$ & 1.0 & & & & & & & & & & & & & & & & & \\
\hline \multirow[t]{2}{*}{2} & $\operatorname{Cer}\left[t_{0}-t_{5}\right]$ & $0.5^{*}$ & 1.00 & & & & & & & & & & & & & & & & \\
\hline & & 0.00 & & & & & & & & & & & & & & & & & \\
\hline \multirow[t]{2}{*}{3} & $\operatorname{Cer}\left[t_{0}-t_{10}\right]$ & $0.3^{*}$ & $0.79 *$ & 1.00 & & & & & & & & & & & & & & & \\
\hline & & 0.00 & 0.00 & & & & & & & & & & & & & & & & \\
\hline \multirow[t]{2}{*}{4} & Beta & 0.14 & $0.3^{*}$ & 0.18 & 1.00 & & & & & & & & & & & & & & \\
\hline & & 0.03 & 0.00 & 0.01 & & & & & & & & & & & & & & & \\
\hline \multirow[t]{2}{*}{5} & Recsm & $-0.27^{*}$ & $-0.23^{*}$ & -0.15 & -0.13 & 1.00 & & & & & & & & & & & & & \\
\hline & & 0.00 & 0.00 & 0.03 & 0.05 & & & & & & & & & & & & & & \\
\hline \multirow[t]{2}{*}{6} & Mricd & $-0.23^{*}$ & $-0.31^{*}$ & $-0.22^{*}$ & -0.13 & $0.31^{*}$ & 1.00 & & & & & & & & & & & & \\
\hline & & 0.00 & 0.01 & 0.01 & 0.05 & 0.00 & & & & & & & & & & & & & \\
\hline \multirow[t]{2}{*}{7} & Age & -0.11 & -017 & -0.12 & -0.02 & -0.03 & 1.00 & & & & & & & & & & & & \\
\hline & & 0.09 & 0.01 & 0.08 & 0.81 & 0.68 & & & & & & & & & & & & & \\
\hline \multirow[t]{2}{*}{8} & Hack & -0.15 & -.11 & -0.17 & -0.01 & $0.23^{*}$ & 0.04 & 1.00 & & & & & & & & & & & \\
\hline & & 0.02 & 0.11 & 0.01 & 0.83 & 0.00 & 0.50 & & & & & & & & & & & & \\
\hline \multirow[t]{2}{*}{9} & nd & 0.10 & 0.09 & 0.05 & 0.03 & -0.07 & -0.09 & -0.19 & 1.00 & & & & & & & & & & \\
\hline & & 0.13 & 0.16 & 0.41 & 0.62 & 0.28 & 0.17 & 0.00 & & & & & & & & & & & \\
\hline \multirow[t]{2}{*}{10} & Ds & -0.02 & 0.00 & -0.04 & -0.01 & -0.05 & -0.06 & $-0.30^{*}$ & -0.18 & 1.00 & & & & & & & & & \\
\hline & & 0.7 & 09 & 0.58 & 0.87 & 0.46 & 0.34 & 0.00 & 0.01 & & & & & & & & & & \\
\hline \multirow[t]{2}{*}{11} & Car & -0.01 & -0.08 & -0.03 & -0.02 & -0.03 & 0.08 & -0.08 & -0.05 & -0.07 & 1.00 & & & & & & & & \\
\hline & & .84 & 02 & 0.63 & 0.74 & 0.65 & 0.25 & 0.26 & 0.49 & 0.28 & & & & & & & & & \\
\hline \multirow[t]{2}{*}{12} & Port & .2 & 0.06 & 0.12 & 0.10 & -0.10 & 0.11 & $-0.28^{*}$ & -0.17 & $-0.26^{*}$ & -0.07 & 1.00 & & & & & & & \\
\hline & & 0.6 & 0.3 & 0.08 & 0.15 & 0.12 & 0.11 & 0.00 & 0.01 & 0.00 & 0.32 & & & & & & & & \\
\hline \multirow[t]{2}{*}{13} & Stat & 00 & 0.01 & 0.03 & -0.01 & -0.04 & 0.05 & -0.09 & -0.06 & -0.09 & -0.02 & -0.08 & 1.00 & & & & & & \\
\hline & & 0.75 & 0.85 & .0 & 0.83 & 0.58 & 0.48 & 0.16 & 0.40 & 0.18 & 0.74 & 0.22 & & & & & & & \\
\hline \multirow[t]{2}{*}{14} & Phys & 0.8 & -0.02 & 0.05 & -0.4 & -0.09 & -0.03 & $-0.22^{*}$ & -0.14 & $-0.21^{*}$ & -0.05 & -0.20 & -0.07 & 1.00 & & & & & \\
\hline & & 0.20 & 0.79 & .4 & 0.57 & 0.17 & 0.70 & 0.00 & 0.04 & 0.00 & 0.42 & 0.00 & 0.32 & & & & & & \\
\hline \multirow[t]{2}{*}{15} & Unkn & 0.05 & 0.02 & 0.02 & -0.0 & 0.13 & -0.08 & -0.12 & -0.07 & -0.11 & -0.03 & -0.11 & -0.03 & -0.09 & 1.00 & & & & \\
\hline & & 0.43 & 072 & 0.3 & 0.16 & 0.06 & 0.21 & 0.07 & 0.27 & 0.08 & 0.67 & 0.11 & 0.60 & 0.20 & & & & & \\
\hline
\end{tabular}


Table 8. Continued

\begin{tabular}{|c|c|c|c|c|c|c|c|c|c|c|c|c|c|c|c|c|c|c|c|}
\hline & VVariables & 1 & 2 & 3 & 4 & 5 & 6 & 7 & 8 & 9 & 10 & 11 & 12 & 1 & 14 & 15 & 16 & 17 & 18 \\
\hline 16 & Lntr & -0.10 & 0.02 & 0.08 & 0.04 & 0.02 & 0.15 & -0.03 & 0.01 & 0.15 & -0.09 & 0.00 & 0.06 & -0.15 & 0.02 & 1.00 & & & \\
\hline & & 0.12 & 0.78 & 0.23 & 0.50 & 0.75 & 0.02 & 0.69 & 0.93 & 0.02 & 0.16 & 1.00 & 0.33 & 0.03 & 0.80 & & & & \\
\hline 17 & Lnta & 0.12 & 0.10 & -0.10 & 0.1 & -0.28 & -0.17 & 0.09 & 0.05 & 0.03 & -0.07 & -0.09 & -0.19 & 0.17 & 0.70 & 0.00 & 1.00 & & \\
\hline & & 0.08 & 0.15 & 0.12 & 0.11 & 0.00 & 0.01 & 0.16 & 0.41 & 0.62 & 0.28 & 0.17 & 0.00 & 0.13 & -0.08 & -0.12 & & & \\
\hline 18 & Lnoi & 0.10 & 0.9 & 0.05 & 0.03 & -0.07 & -0.09 & 0.17 & 0.70 & 0.00 & 0.04 & 0.00 & 0.08 & 0.67 & 0.11 & 0.09 & 0.05 & 1.00 & \\
\hline & & 0.13 & 0.16 & 0.41 & 0.62 & 0.28 & 0.17 & 0.13 & -0.08 & -0.12 & -0.07 & -0.11 & 0.15 & -0.09 & 0.00 & 0.16 & 0.41 & & \\
\hline 19 & Noemp & 0.16 & 0.41 & 0.62 & 0.28 & 0.17 & 0.00 & 0.10 & -0.10 & 0.11 & -0.28 & -0.17 & -0.26 & -0.17 & -0.12 & -0.02 & -0.03 & -0.05 & 1.00 \\
\hline & & 0.00 & -0.04 & -.01 & -0.05 & -0.06 & -0.30 & 0.15 & 0.12 & 0.11 & 0.00 & 0.01 & 0.00 & 0.01 & 0.08 & 0.81 & 0.68 & 0.49 & \\
\hline
\end{tabular}

${ }^{*} p<0.1$ 
Table 9. Regression Results: regressing CER over selected variables at different intervals

\begin{tabular}{|c|c|c|c|}
\hline Model / & (1) & (2) & (3) \\
\hline Variables & $\operatorname{Cer}\left[\mathrm{t}_{0}\right]$ & $\operatorname{Cer}\left[t_{0}-t_{5}\right]$ & $\operatorname{Cer}\left[\mathrm{t}_{0}-\mathrm{t}_{10}\right]$ \\
\hline \multirow[t]{2}{*}{ Recsm } & $-0.000223 * * *$ & $-0.000513 * * *$ & $-0.000338 *$ \\
\hline & $(0.00006)$ & $(0.000155)$ & $(0.000196)$ \\
\hline \multirow[t]{2}{*}{ Beta } & $-0.00508^{*}$ & $-0.0259 * * *$ & $-0.0306^{* * *}$ \\
\hline & $(0.00289)$ & $(0.00758)$ & $(0.00956)$ \\
\hline \multirow[t]{2}{*}{ Age } & -0.000036 & $-0.000242^{* *}$ & $-0.000220^{*}$ \\
\hline & $(0.0004)$ & $(0.0001)$ & $(0.000123)$ \\
\hline \multirow[t]{2}{*}{ Lntr } & -0.000360 & 0.000451 & 0.00291 \\
\hline & $(0.000553)$ & $(0.00145)$ & $(0.00183)$ \\
\hline \multirow[t]{2}{*}{ Hack } & -0.0096 & -0.00934 & -0.0250 \\
\hline & $(0.00645)$ & $(0.0169)$ & $(0.0213)$ \\
\hline \multirow[t]{2}{*}{ Insd } & -0.00363 & 0.00172 & -0.00373 \\
\hline & $(0.00667)$ & $(0.0175)$ & $(0.0221)$ \\
\hline \multirow[t]{2}{*}{ Disc } & -0.00801 & -0.00975 & -0.0203 \\
\hline & $(0.00646)$ & $(0.0169)$ & $(0.0213)$ \\
\hline \multirow[t]{2}{*}{ Card } & -0.0136 & -0.0392 & -0.0326 \\
\hline & $(0.0107)$ & $(0.0280)$ & $(0.0353)$ \\
\hline \multirow[t]{2}{*}{ Port } & -0.00573 & -0.00228 & 0.00718 \\
\hline & $(0.00642)$ & $(0.0168)$ & $(0.0212)$ \\
\hline \multirow[t]{2}{*}{ Stat } & -0.00767 & -0.00187 & -0.00140 \\
\hline & $(0.00941)$ & $(0.0247)$ & $(0.0311)$ \\
\hline \multirow[t]{2}{*}{ Phys } & -0.00630 & -0.00496 & -0.00241 \\
\hline & $(0.00679)$ & $(0.0178)$ & $(0.0224)$ \\
\hline Industry effect & Included & Included & Included \\
\hline Year effect & Included & Included & Included \\
\hline Observations & 232 & 232 & 232 \\
\hline $\operatorname{Adj~} r^{2}$ & 0.163 & 0.235 & 0.188 \\
\hline F-test & $1.34 *$ & $2.12 * * *$ & $1.60 * *$ \\
\hline
\end{tabular}

Standard errors in parentheses ${ }^{* * *} p<0.01,{ }^{* *} p<0.05,{ }^{*} p<0.1$

RecsM is The number of records affected by the data breach in millions.

Beta is the systematic risk.

LnTR is the natural logarithm of total revenue.

Hack, Insd, Disc, Card, Port, Stat, Phys are the types of breaches, as in Appendix A.3. 
Table 10. Regression Results: regressing CER over selected variables at different intervals

\begin{tabular}{|c|c|c|c|}
\hline Model / & (1) & (2) & (3) \\
\hline Variables & $\operatorname{Cer}\left[t_{0}\right]$ & $\operatorname{Cer}\left[t_{0}-t_{5}\right]$ & $\operatorname{Cer}\left[\mathrm{t}_{0}-\mathrm{t}_{10}\right]$ \\
\hline \multirow[t]{2}{*}{ Recsm } & $-0.000147 * *$ & $-0.000321^{*}$ & -0.000215 \\
\hline & $(7.04 \mathrm{e}-05)$ & $(0.000188)$ & $(0.000233)$ \\
\hline \multirow[t]{2}{*}{ Mricd $^{1}$} & $-0.0260^{* *}$ & $-0.0968 * * *$ & $-0.0818 * *$ \\
\hline & $(0.0113)$ & $(0.0301)$ & $(0.0373)$ \\
\hline \multirow[t]{2}{*}{ Age } & -0.00000043 & $-0.000269^{*}$ & $-0.000385^{* *}$ \\
\hline & $(0.000058)$ & $(0.000155)$ & $(0.000191)$ \\
\hline \multirow[t]{2}{*}{ Hack } & $-0.0179 * *$ & -0.00953 & -0.0116 \\
\hline & $(0.00846)$ & $(0.0226)$ & $(0.0280)$ \\
\hline \multirow[t]{2}{*}{ Insd } & -0.00849 & -0.00937 & 0.000752 \\
\hline & $(0.00864)$ & $(0.0231)$ & $(0.0286)$ \\
\hline \multirow[t]{2}{*}{ Disc } & $-0.0192 * *$ & -0.0360 & -0.0369 \\
\hline & $(0.00849)$ & $(0.0227)$ & $(0.0281)$ \\
\hline \multirow[t]{2}{*}{ Card } & -0.00659 & -0.0747 & -0.0601 \\
\hline & $(0.0219)$ & $(0.0585)$ & $(0.0724)$ \\
\hline \multirow[t]{2}{*}{ Port } & -0.00881 & -0.0108 & 0.00671 \\
\hline & $(0.00814)$ & $(0.0218)$ & $(0.0270)$ \\
\hline \multirow[t]{2}{*}{ Stat } & -0.0220 & -0.0182 & 0.0105 \\
\hline & $(0.0167)$ & $(0.0447)$ & $(0.0553)$ \\
\hline \multirow[t]{2}{*}{ Phys } & -0.0123 & -0.0103 & 0.00145 \\
\hline & $(0.00890)$ & $(0.0238)$ & $(0.0295)$ \\
\hline \multirow[t]{2}{*}{ Lntr } & -0.000911 & 0.000499 & 0.00519 \\
\hline & $(0.00137)$ & $(0.00368)$ & $(0.00455)$ \\
\hline \multirow[t]{2}{*}{ Lnta } & 0.00067 & 0.000173 & -0.00146 \\
\hline & $(0.000884)$ & $(0.00236)$ & $(0.00293)$ \\
\hline \multirow[t]{2}{*}{ Lnoi } & 0.00029 & 0.000667 & 0.000950 \\
\hline & $(0.00148)$ & $(0.00396)$ & $(0.00490)$ \\
\hline \multirow[t]{2}{*}{ Lnnoemp } & $5.43 \mathrm{e}-09$ & $9.31 \mathrm{e}-09$ & $1.71 \mathrm{e}-09$ \\
\hline & $(5.07 \mathrm{e}-09)$ & $(1.36 \mathrm{e}-08)$ & $(1.68 \mathrm{e}-08)$ \\
\hline Industry effect & Included & Included & Included \\
\hline Year effect & Included & Included & Included \\
\hline \multirow[t]{2}{*}{ Constant } & -0.0138 & -0.0233 & -0.118 \\
\hline & $(0.0281)$ & $(0.0753)$ & $(0.0932)$ \\
\hline Observations & 163 & 163 & 163 \\
\hline Adj $r^{2}$ & 0.226 & 0.280 & 0.222 \\
\hline F-test & $1.19^{*}$ & $1.58^{* *}$ & 1.16 \\
\hline
\end{tabular}

Standard errors in parentheses ${ }^{* * *} p<0.01,{ }^{* *} p<0.05,{ }^{*} p<0.1$

'Management's Report on Internal Control deficiencies.

$\mathrm{Ln} T A$ is the natural algorithm of total assets.

$\mathrm{LnOl}$ is the natural algorithm of operating income.

LnNoEmp is the natural algorithm of the number of employees. 
Table 11. Regression Results: regressing $10 \mathrm{KDB}^{ \pm}$over selected variables.

\begin{tabular}{|c|c|c|c|}
\hline Model / & (1) & (2) & (3) \\
\hline Variables & $10 \mathrm{kdb}$ & $10 \mathrm{kdb}$ & $10 \mathrm{kdb}$ \\
\hline \multirow[t]{2}{*}{ Recsm } & $0.00489^{* *}$ & $0.00369^{* * *}$ & $0.00351 * * *$ \\
\hline & $(0.001)$ & $(0.001)$ & $(0.001)$ \\
\hline \multirow[t]{2}{*}{ Age } & 0.00065 & 0.00120 & 0.00094 \\
\hline & $(0.001)$ & $(0.001)$ & $(0.001)$ \\
\hline \multirow[t]{2}{*}{ Hack } & 0.14800 & 0.11800 & 0.12300 \\
\hline & $(0.116)$ & (0.118) & $(0.137)$ \\
\hline \multirow[t]{2}{*}{ Insd } & -0.01300 & -0.03200 & -0.00147 \\
\hline & $(0.129)$ & $(0.129)$ & $(0.140)$ \\
\hline \multirow[t]{2}{*}{ Disc } & 0.11700 & 0.08330 & 0.11200 \\
\hline & $(0.118)$ & $(0.120)$ & $(0.137)$ \\
\hline \multirow[t]{2}{*}{ Card } & -0.05410 & -0.04230 & 0.03780 \\
\hline & $(0.335)$ & $(0.332)$ & $(0.358)$ \\
\hline \multirow[t]{2}{*}{ Port } & -0.00163 & -0.00020 & 0.05750 \\
\hline & $(0.119)$ & $(0.120)$ & $(0.132)$ \\
\hline \multirow[t]{2}{*}{ Stat } & -0.0686 & -0.17600 & -0.16500 \\
\hline & $(0.242)$ & $(0.246)$ & $(0.270)$ \\
\hline \multirow[t]{2}{*}{ Phys } & 0.05010 & 0.04180 & 0.04710 \\
\hline & $(0.123)$ & $(0.128)$ & $(0.144)$ \\
\hline \multirow[t]{2}{*}{ Lntr } & 0.01730 & 0.02280 & 0.02180 \\
\hline & $(0.021)$ & $(0.021)$ & $(0.023)$ \\
\hline \multirow[t]{2}{*}{ Lnta } & 0.00546 & 0.00633 & 0.00672 \\
\hline & $(0.014)$ & $(0.014)$ & $(0.014)$ \\
\hline \multirow[t]{2}{*}{ Lnoi } & -0.02060 & -0.03320 & -0.03390 \\
\hline & $(0.022)$ & $(0.022)$ & $(0.024)$ \\
\hline \multirow[t]{2}{*}{ Lnnoemp } & $-5.59 \mathrm{e}-08$ & $-2.23 e-08$ & $-5.08 \mathrm{e}-08$ \\
\hline & (7.36e-08) & (7.69e-08) & $(8.27 \mathrm{e}-08)$ \\
\hline Industry effect & & & Included \\
\hline \multirow[t]{2}{*}{ Year effect } & & Included & Included \\
\hline & & $(0.224)$ & $(0.239)$ \\
\hline \multirow[t]{2}{*}{ Constant } & -0.0875 & 0.395 & 0.344 \\
\hline & $(0.301)$ & $(0.398)$ & $(0.461)$ \\
\hline Observations & 163 & 163 & 163 \\
\hline Adj $r^{2}$ & 0.173 & 0.220 & 0.282 \\
\hline F-test & $2.40 * * *$ & $2.25 * * *$ & $1.66^{* *}$ \\
\hline
\end{tabular}

Standard errors in parentheses ${ }^{* * *} p<0.01,{ }^{* *} p<0.05,{ }^{*} p<0.1$

${ }^{ \pm}$For data breach inclusion in financial statements, $10 \mathrm{KDB}=1$, and 0 otherwise. 
Table 12. Regression Results: Regressing the CER, negative or not ${ }^{ \pm}$, over selected variables

\begin{tabular}{|c|c|c|c|}
\hline Model / & (1) & (2) & (3) \\
\hline Variables & $\operatorname{Cer}\left[t_{0}-t_{20}\right]$ & $\operatorname{Cer}\left[t_{0}-t_{20}\right]$ & $\operatorname{Cer}\left[t_{0}-t_{20}\right]$ \\
\hline \multirow[t]{2}{*}{ Recsm } & $-0.00311^{*}$ & $-0.00309 *$ & $-0.00297 *$ \\
\hline & $(0.00170)$ & $(0.00173)$ & $(0.00175)$ \\
\hline \multirow[t]{2}{*}{ Age } & 0.000752 & 0.000270 & 0.000322 \\
\hline & $(0.000983)$ & $(0.00103)$ & $(0.00106)$ \\
\hline \multirow[t]{2}{*}{$\Delta$ Beta } & $-0.115^{*}$ & $-0.121 *$ & $-0.110 *$ \\
\hline & $(0.0648)$ & $(0.0653)$ & $(0.0657)$ \\
\hline \multirow[t]{2}{*}{$\Delta$ St.dev } & 4.227 & 3.687 & 3.197 \\
\hline & (3.920) & (3.997) & (4.289) \\
\hline \multirow[t]{2}{*}{ Lntr } & 0.0129 & 0.0157 & 0.0111 \\
\hline & $(0.0145)$ & $(0.0154)$ & $(0.0159)$ \\
\hline \multirow[t]{2}{*}{ Hack } & 0.272 & $0.330 *$ & $0.440 * *$ \\
\hline & $(0.173)$ & $(0.176)$ & $(0.192)$ \\
\hline \multirow[t]{2}{*}{ Insd } & 0.0114 & 0.0381 & 0.121 \\
\hline & $(0.19)$ & $(0.192)$ & $(0.198)$ \\
\hline \multirow[t]{2}{*}{ Disc } & 0.0824 & 0.118 & 0.239 \\
\hline & $(0.175)$ & $(0.179)$ & $(0.192)$ \\
\hline \multirow[t]{2}{*}{ Card } & 0.325 & 0.358 & $0.594 *$ \\
\hline & $(0.29)$ & $(0.301)$ & $(0.309)$ \\
\hline \multirow[t]{2}{*}{ Port } & 0.104 & 0.128 & 0.212 \\
\hline & $(0.178)$ & $(0.180)$ & $(0.192)$ \\
\hline \multirow[t]{2}{*}{ Stat } & 0.0570 & 0.0869 & 0.231 \\
\hline & $(0.26)$ & $(0.261)$ & $(0.274)$ \\
\hline \multirow[t]{2}{*}{ Phys } & 0.0984 & 0.186 & 0.293 \\
\hline & $(0.185)$ & (0.189) & $(0.201)$ \\
\hline Industry effect & & Included & Included \\
\hline Year effect & & & Included \\
\hline \multirow[t]{2}{*}{ Constant } & 0.0908 & -0.123 & -0.304 \\
\hline & $(0.368)$ & $(0.421)$ & $(0.448)$ \\
\hline Observations & 232 & 232 & 232 \\
\hline Adj $r^{2}$ & 0.064 & 0.088 & 0.157 \\
\hline F-test & $1.33^{*}$ & 1.19 & $1.23 *$ \\
\hline
\end{tabular}

Standard errors in parentheses ${ }^{* *} p<0.01,{ }^{* *} p<0.05,{ }^{*} p<0.1$;

${ }^{ \pm} \mathrm{CER}[0,20]<0=1,0$ otherwise.

$\Delta B$ eta is the difference of beta in the event window and the estimation window to measure the systematic risk of breached companies.

$\Delta S t . D e v$ is the difference of standard deviation in the event window and in the estimation window to measure the overall risk of breached companies. 


\section{APPENDIX IV.}

\section{Examples of Previous Research}

\begin{tabular}{|c|c|c|c|c|}
\hline Author(s) & Source & Total sample & Event study, windows \& variables & Remarks \\
\hline $\begin{array}{l}\text { (Deane et al., } \\
\text { 2019) }\end{array}$ & It\&m & 111 events & $\operatorname{Ev}[-1,0]$, estw[-300, -46$]$ & $\begin{array}{l}\text { The capacity for information security management } \\
\text { program investments to generate value for firms } \\
\text { and further offers guidance for practitioners } \\
\text { seeking to maximize shareholder value. }\end{array}$ \\
\hline $\begin{array}{l}\text { (Chatterjee et al., } \\
\text { 2019) }\end{array}$ & Jbr & 72 firms & Ev $[-1,2]$, est windo $[-252,-21]$ & $\begin{array}{l}\text { Breach scope affects stock market reactions when } \\
\text { the stories stress fear over anger. }\end{array}$ \\
\hline $\begin{array}{l}\text { (Rosati et al., } \\
\text { 2019) }\end{array}$ & Riib\&f & $\begin{array}{l}87 \text { breaches, } 73 \\
\text { us firms }\end{array}$ & $E v[0,1], \ldots[4,10]$ & $\begin{array}{l}\text { Needs for a contingency model for social media } \\
\text { communication during the firm crisis. }\end{array}$ \\
\hline $\begin{array}{l}\text { (Richardson et al., } \\
\text { 2019) }\end{array}$ & Jis & $\begin{array}{l}417 \text { companies \& } \\
827 \text { breaches }\end{array}$ & $\begin{array}{l}\text { Ev [-1,3] ... [-1,21], future performance, } \\
\text { future audit fees, control firms }\end{array}$ & $\begin{array}{l}\text { Market returns for breach companies are nominally } \\
\text { lower, but not significantly different than the } \\
\text { matched companies. }\end{array}$ \\
\hline $\begin{array}{l}\text { (Rosati et al., } \\
\text { 2018) }\end{array}$ & Jbr & $\begin{array}{l}5 \text { cases /1 firm } \\
2018\end{array}$ & The event day & Four out of five cases showed negative effects. \\
\hline $\begin{array}{l}\text { (Rosati et al., } \\
\text { 2018) }\end{array}$ & $\begin{array}{l}\text { Proc.51hic } \\
\text { ss }\end{array}$ & $\begin{array}{l}32 \text { breaches } / 29 \\
\text { us firms } \\
2011-2014\end{array}$ & $\begin{array}{l}\text { Ev }[0,1],[0,2],[0,3],[0,4],[0,5] \\
\text { Media, tweet, type, records, prior breach, } \\
\text { size, growth, year fixed effect. }\end{array}$ & $\begin{array}{l}\text { Social media disclosure exacerbates the negative } \\
\text { stock price's response to the announcement. }\end{array}$ \\
\hline $\begin{array}{l}\text { (Tweneboah-kodua } \\
\text { et al., 2018) }\end{array}$ & $\begin{array}{l}\text { Info. \& } \\
\text { comp. Sec. }\end{array}$ & 96 firms & $\begin{array}{l}\text { Ev }[-1,1],[-2,2] \ldots[-10,10] \text { estw } \\
{[-260,-11]}\end{array}$ & $\begin{array}{l}\text { Financial sector firms tend to react cumulatively } \\
\text { to cyberattacks over three days than other sectors, } \\
\text { and technology firms tend to be less reactive to the } \\
\text { announcement of a data breach. }\end{array}$ \\
\hline $\begin{array}{l}\text { (Rosati et al., } \\
\text { 2017) }\end{array}$ & Irfa & $\begin{array}{l}74 \text { breaches } \\
2005-2014\end{array}$ & $\begin{array}{l}\text { Es }[-132,-6], \text { ev }[0,2] \\
\text { Bed-ask spread, financial variables, } \\
\text { breach scale, prior, type, industry. }\end{array}$ & $\begin{array}{l}\text { The positive short-term effect on both bid-ask } \\
\text { spread and trading volume. }\end{array}$ \\
\hline $\begin{array}{l}\text { (Martin et al., } \\
\text { 2017) }\end{array}$ & $\mathrm{Jm}$ & $\begin{array}{l}414 \text { public } \\
\text { companies }\end{array}$ & $\begin{array}{l}\text { Ev }[0],[-1,0],[0,1],[-1,1] \\
\text { Returns, security, capital slack, size, } \\
\text { number of breaches, industry \& year fixed } \\
\text { effect. }\end{array}$ & $\begin{array}{l}\text { Negative effects. Spillover vulnerabilities from } \\
\text { rival firms' breaches on firm performance. }\end{array}$ \\
\hline $\begin{array}{l}\text { (Schatz \& } \\
\text { bashroush, 2016) }\end{array}$ & $\mathrm{I} \& \mathrm{cs}$ & 25 breaches & $\begin{array}{l}\text { Es }[-121,-3], \text { ev }[-2,2] \\
\text { Single \& repeated events. }\end{array}$ & $\begin{array}{l}\text { Negative performance. The effect worsens when } \\
\text { a firm has experienced more than one breach, but } \\
\text { weak statistical evidence. }\end{array}$ \\
\hline $\begin{array}{l}\text { (Bose \& leung, } \\
\text { 2013) }\end{array}$ & Dss & $\begin{array}{l}87 \text { announcements } \\
1995-2012\end{array}$ & $\begin{array}{l}\text { Es }[-230,-31] \text {, ev }[-2,2],[0,1] \\
\text { Identity theft. }\end{array}$ & $\begin{array}{l}\text { Investors reward growing firms and small } \\
\text { companies more if they adopt the countermeasures } \\
\text { (investment in anti-identity theft). }\end{array}$ \\
\hline $\begin{array}{l}\text { (Benaroch et al., } \\
\text { 2012) }\end{array}$ & Ijais & $\begin{array}{l}162 \text { events, } \\
1985-2009\end{array}$ & $\begin{array}{l}\text { Es [-301, }-46], \text { ev }[-1,1],[-1,2],[-1,3], \\
{[0,1][0,2],[0,3] ; \text { confidentiality, integrity, }} \\
\text { availability. }\end{array}$ & $\begin{array}{l}\text { Negative reactions, and it is stronger for firms with } \\
\text { high growth potential, firms that are larger, riskier, } \\
\text { and banking sector. }\end{array}$ \\
\hline $\begin{array}{l}\text { (Malhotra \& } \\
\text { kubowicz malhotra, } \\
\text { 2011) }\end{array}$ & $\mathrm{Jsr}$ & 93 firm & $\begin{array}{l}\text { Es }[-256,-2] \text {, ev }[-1,1],[2,30] \\
\text { Customer data, severity. }\end{array}$ & $\begin{array}{l}\text { The negative effect in the short and long runs; } \\
\text { more detrimental in the long run and for large } \\
\text { breaches. Larger firms suffer greater market value } \\
\text { loss than smaller firms. }\end{array}$ \\
\hline (Yayla \& hu, 2011) & Jit & $\begin{array}{l}123 \text { events } \\
1994-2006\end{array}$ & $\begin{array}{l}\text { Es }[-130,-10] \text {, ev }\{-1,1],[-1,5],[-1,10] \text {; } \\
\text { different types }\end{array}$ & Significant negative for the overall sample \\
\hline $\begin{array}{l}\text { (Gordon et al., } \\
\text { 2011) }\end{array}$ & $J C S$ & $\begin{array}{l}\text { 121events } \\
1995-2007\end{array}$ & $\begin{array}{l}\text { Es }[-121,-2] \\
\text { Ev }[-1,1] \\
\text { Security, breach type }\end{array}$ & Significant negative for overall sample \\
\hline $\begin{array}{l}\text { (Goldstein et al., } \\
\text { 2011) }\end{array}$ & Jais & $\begin{array}{l}142 \text { events } \\
1985-2010\end{array}$ & $\begin{array}{l}{[-3,3]} \\
\text { Strategic resource }\end{array}$ & Negative effects \\
\hline $\begin{array}{l}\text { (Bolster et al., } \\
\text { 2010) }\end{array}$ & $J b v \& e l a$ & $\begin{array}{l}93 \text { data breaches } \\
2000-2007\end{array}$ & {$[-1,0],[-1,1],[1,30]$} & Negative effects for certain outlets \\
\hline (Patel, 2010) & Dje & $\begin{array}{l}34 \\
2001-2009\end{array}$ & $\begin{array}{l}\text { Es }[-50,-1], \text { ev }[0,3],[0,8],[0,30] \\
\text { S\&p, security, confidential data (ss\#, } \\
\text { credit card\#) }\end{array}$ & Significant negative on $[0,8]$ \\
\hline $\begin{array}{l}\text { (Gatzlaff \& } \\
\text { mccullough, 2010) }\end{array}$ & Rm\&ir & $\begin{array}{l}77 \text { events } \\
2004-2006\end{array}$ & $\begin{array}{l}\text { Es [-252, }-7], \text { ev }[-5,0],[0,180] \\
\text { Confidential data, customer \& employee }\end{array}$ & $\begin{array}{l}\text { Negative effects of confidentiality events. Sig. } \\
\text { Higher costs for smaller firms }\end{array}$ \\
\hline
\end{tabular}




\begin{tabular}{|c|c|c|c|c|}
\hline Author(s) & Source & Total sample & Event study, windows \& variables & Remarks \\
\hline (Wang, 2010) & Misq & $\begin{array}{l}88 \text { data breaches } \\
\text { (virus \& others) } \\
1997-2007\end{array}$ & Design science & No significant effects \\
\hline $\begin{array}{l}\text { (Leung \& bose, } \\
\text { 2008) }\end{array}$ & Icis proc. & $\begin{array}{l}2994 \text { phishing } \\
---2007\end{array}$ & Ev $[-2,2]$ & No significant effects \\
\hline $\begin{array}{l}\text { (Kannan et al., } \\
\text { 2007) }\end{array}$ & Ijec & $\begin{array}{l}72 \text { events } \\
1997-2003\end{array}$ & $\begin{array}{l}\text { Ev }[-1,2],[-1,7],[-1,29] \\
\text { Return, abnormal, industry, }\end{array}$ & No significant effects \\
\hline $\begin{array}{l}\text { (Acquisti et al., } \\
\text { 2006) }\end{array}$ & $\begin{array}{l}27^{\text {th }} \text { icis \& } \\
\text { weis }\end{array}$ & $\begin{array}{l}79 \text { events } \\
2000-03 / 01 / 2006\end{array}$ & $\begin{array}{l}\text { Es }[-100,-8], \text { ev }[-7,10] \\
\text { Misuse of personal data } \\
\text { Firm performance, data breach scale, } \\
\text { scope \& type. }\end{array}$ & $\begin{array}{l}\text { The significant negative effect on the stock market } \\
\text { value announcement day. The cumulative effect } \\
\text { increases the day of the announcement but then } \\
\text { decreases and becomes non-significant over time. }\end{array}$ \\
\hline $\begin{array}{l}\text { (Cavusoglu et al., } \\
\text { 2004) }\end{array}$ & Ijec & $\begin{array}{l}66 \text { events } \\
1996-2001\end{array}$ & $\begin{array}{l}\text { Es }[-160,-1] \\
\text { Ew }[0,0],[0,1] \\
\text { Dos vs. Others. }\end{array}$ & $\begin{array}{l}\text { Negative effects, stronger market reaction to } \\
\text { internet events \& smaller firms. }\end{array}$ \\
\hline $\begin{array}{l}\text { (Hovav \& d'arcy, } \\
\text { 2004) }\end{array}$ & $\begin{array}{l}\text { International } \\
\text { wosis }\end{array}$ & $\begin{array}{l}186 \text { virus-attacks } \\
1998-2002\end{array}$ & $\begin{array}{l}\text { Ev }[0],[0.1],[0,5],[0,10], 0,20] \\
\text { Anecdotes, only virus attacks }\end{array}$ & $\begin{array}{l}\text { No significant negative effects on virus type } \\
\text { integrity events. }\end{array}$ \\
\hline $\begin{array}{l}\text { (Hovav \& d'arcy, } \\
\text { 2003) }\end{array}$ & Rm\&ir & $\begin{array}{l}23 \text { dos, } 20 \text { firms } \\
1998-2002\end{array}$ & $\begin{array}{l}\text { Event study es }[-201,-2] \\
\text { Ew [-1,0], [-1.1], [-1,5], [-1, 10], -1,25] } \\
\text { S\&p 500, dos attack }\end{array}$ & $\begin{array}{l}\text { Mix effect, the negative abnormal returns of } \\
\text { the internet-specific companies ere larger. No } \\
\text { significant negative effects on dos, except for } \\
\text { internet companies with higher costs. }\end{array}$ \\
\hline $\begin{array}{l}\text { (Campbell et al., } \\
\text { 2003) }\end{array}$ & $J c s$ & $\begin{array}{l}43 \text { events } \\
1995-2000\end{array}$ & $\begin{array}{l}\text { Es }[-121,-2], \text { ev }[-1,1] \\
\text { Access to confidential or not }\end{array}$ & $\begin{array}{l}\text { No significant negative market reaction to } \\
\text { confidential data breaches. }\end{array}$ \\
\hline (Garg et al., 2003) & $\operatorname{Im} \& \mathrm{cs}$ & $\begin{array}{l}22 \text { events } \\
1999-2002\end{array}$ & $\begin{array}{l}\text { Es }[0,0],[0,1],[0,2] \\
\text { Anecdotes, different types of loss data }\end{array}$ & $\begin{array}{l}\text { Negative effect to non-virus type security } \\
\text { breaches. }\end{array}$ \\
\hline $\begin{array}{r}\text { (Ettredge \& } \\
\text { richardson, 2003) }\end{array}$ & Ija\&im & 2000 & $\begin{array}{l}E v[0,0],[0,1],[0,2] \\
\quad \operatorname{Dos}\end{array}$ & $\begin{array}{l}\text { Significant negative returns for the firms } \\
\text { attacked. }\end{array}$ \\
\hline
\end{tabular}

5 significant negative IRFA: International Review of Financial Analysis, JM: Journal of Marketing, I\&CS: Information \& Computer Security, DSS: Decision Support Systems, IJAIS: International Journal of Accounting Information Systems, JSR: Journal of Service Research; JIT: Journal of Information Technology, JCS: Journal of Computer Security, JAIS: Journal of the Association for Information Systems, JBV\&ELA: Journal of Business Valuation and Economic LosS Analysis, DJE: Duke J Econ, RM\&IR, MISQ: MIS Quarterly, IJEC: International Journal of Electronic Commerce, RM\&IR: Risk Management and Insurance Review, IM\&CS: Information Management \& Computer Security, IJA\&IM: International Journal of Accounting \& Information Management. Info. \& Comp. Sec: Information \& Computer Security

effects; 10 negative effects; 8 Mix effects or no negative effects.

To acquire quality sources to support our literature review, we chose well-recognized databases to search for relevant work: The Web of Science Core Collection databases, the AAA Digital Library, the Wiley Online Library, Taylor \& Francis Online, and Elsevier. Following that, we identified relevant search terms to be used in the retrieval process and included data breaches and data security incidents as the keywords. During this initial exploratory search, we noticed that our core concept of search (i.e., data breaches) had various synonyms in different databases because of the multidisciplinary nature of the field. For instance, some researchers use the term cybersecurity incidents, data leak, data leakage, privacy violations, or privacy. Through an iterative process, the exact search terms and keywords that were tried in the databases included data AND breach(s), data AND security AND incident(s), cybersecurity AND incident(s), data AND privacy AND incident(s), data AND leak(age), and data AND privacy AND violation(s). We applied the advanced search features in ways that allowed us to maintain consistency across the databases. For our initial review, we searched in the abstract, keyword, and title of the manuscript published, since 2003. We compiled the output of this initial search into an Excel spreadsheet and excluded all duplicates, based on the title and abstract review. We excluded studies that were not published in English. We also excluded conference proceedings, book chapters, any manuscript that didn't undergo a blind peer review according to journal policy. Of the remaining articles, we reviewed the titles and abstracts and included manuscripts that conducted event studies. Finally, we reviewed the full text of the remaining manuscript and selected 23 journals that were relevant to our research, and reported their findings. 
Ahmad Juma'h is an associate professor of accounting at the Accounting Department, University of Illinois Springfield. He is a Certified Public Accountant (CPA), and Certified Management Accountant (CMA). Earlier, he was a professor of Accounting at the Inter American University of Puerto Rico. He coordinated the Doctoral Program in Finance at the Economic School in the Faculty of Business Administration at Inter American University of Puerto Rico, Metropolitan Campus [2011-2020]. He has taught accounting, finance, and strategic management courses in various universities since 1987. He has published in international and professional journals about data breaches, outsourcing, materiality implications, performance measurements, and behavioral accounting and finance.

Yazan Alnsour received his Ph.D. in Information Systems \& Computer Science from the University of Colorado Denver Business School in 2016. He is currently an Assistant Professor of Information Systems at the University of Wisconsin - Oshkosh. Yazan's research interests are in Data \& text analytics, Information Systems Security \& Privacy, and the Business Value of Infosys. His work has been published and presented in multiple international journals and conferences. He has valuable teaching experience delivering courses at the graduate and undergraduate levels in areas like Big Data Analytics, Information Management, Data Mining, Information Security, Cybersecurity Analytics, and Ethical Hacking. 